\title{
تجليات الأسطورة ورموزها في رواية "السيمورغ" لمحمد ديب
}

The manifestations of the legend and its symbols in the novel simorgh by

\author{
Mohammad Dib
}

تاريخ الاستلام : 2020/01/08 ؛ تاريخ القبول : 2020/08/11

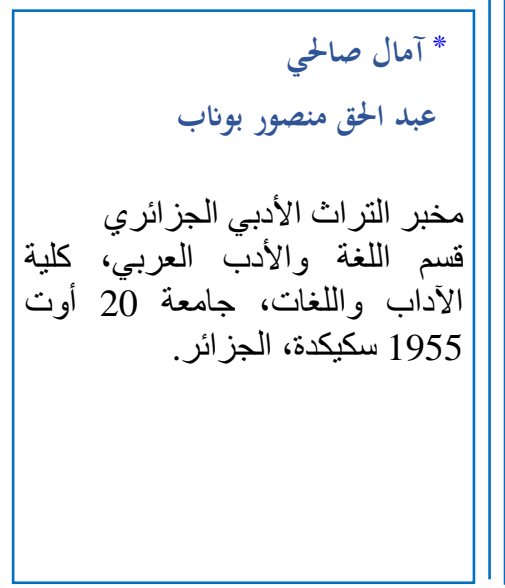

\section{Abstract}

This study seeks to reveal the manifestations of the legend and its symbols in the novel Simorgh by Mohammad Dib. We find that the writer was inspired by the legendary heritage and used it in the folds of his romantic discourse, relying on the mechanisms of the legendary techniques to clarify this use and show his legendary references and symbols and the manner of the use of these legendary elements and their presence in the novel. They were based in their artistic construction and their coherent and cohesive general structure on the legend of Simorgh / the Phoenix in addition to several Eastern and Western legends, joining the structure of the novel to form a basic essence in the process of reading and analysis of this romantic discourse. This use allowed him to express various questions related to the reality and the human self in an artistic way, opening the door of creativity, embodying his visions and presenting his reflections and ideas.

Keywords: legend ; symbol ; romantic discourse ; Mohammad Dib ; Simorgh.

\begin{abstract}
Résumé
Cette étude cherche à révéler les manifestations de la légende et de ses symboles dans le roman "Simorgh" de Mohammad Dib, dans lequel nous constatons que l'écrivain s'est inspiré de l'héritage légendaire et l'a employé dans les plis de son discours romanesque, en s'appuyant sur les mécanismes de l'approche légendaire et ses techniques pour clarifier cet emploi et montrer ses références et symboles légendaires et la manière de l'utilisation de ces éléments légendaires et leur présence dans le roman. Ces derniers ont été basés dans leur construction artistique et leur structure générale cohérente et cohésive sur la légende de Simorgh / le Phénix en plus de plusieurs légendes orientales et occidentales, rejoignant la structure du roman pour former une essence de base dans le processus de lecture et d'analyse de ce discours romanesque. Cet emploi lui a permis d'exprimer des diverses questions liées à la réalité et le soi humain d'une manière artistique et d'ouvrir la porte de la créativité, l'incarnation de ses visions et présenter ses réflexions et idées.
\end{abstract}

Mots clés: légende; symbole; discours romanesque; Mohammad Dib ; Simorgh .

* Corresponding author, e-mail: salhiamel2018@gmail.com 
تعد الأسطورة منظومة ثقافية متمبزة ذات خصوصية عالية، فهي المخزون الثقافي

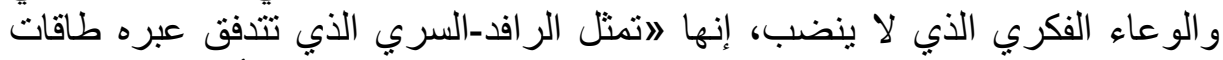

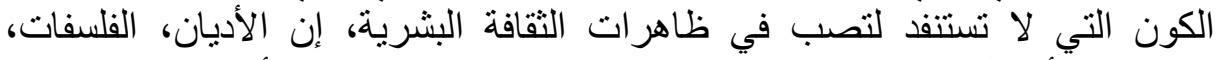

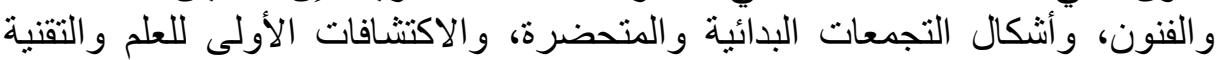

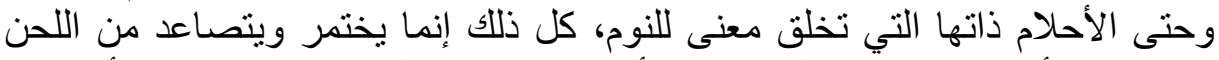

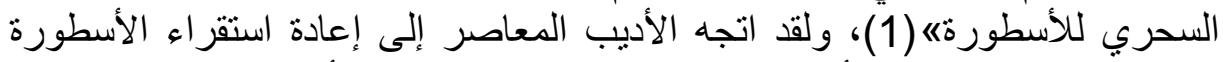

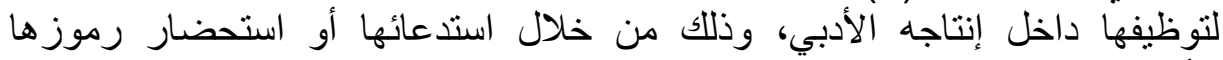

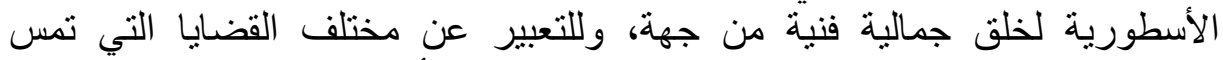

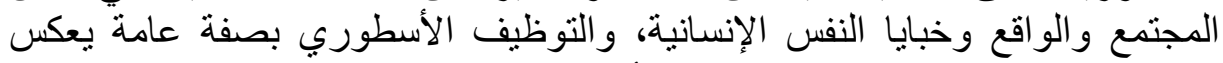

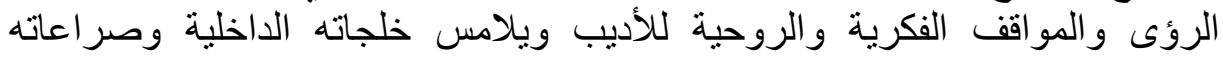

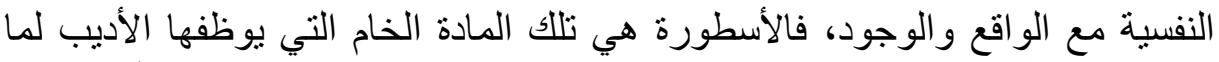

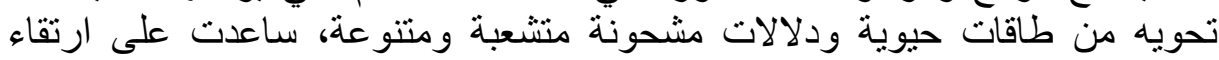
الأدب ومكنت الأديب من خلق صور إيحائية يختلط فيها الخيال بالإلبد الإنداع.

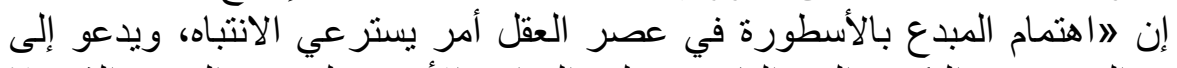

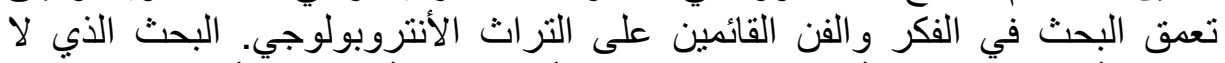

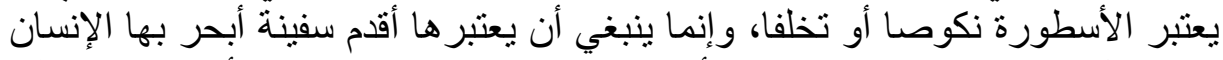

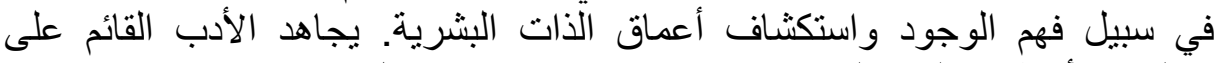

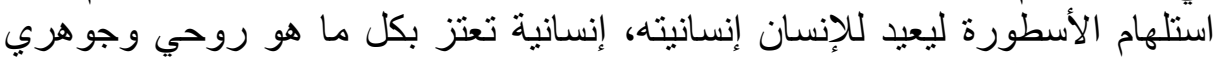

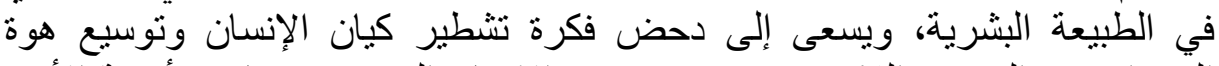

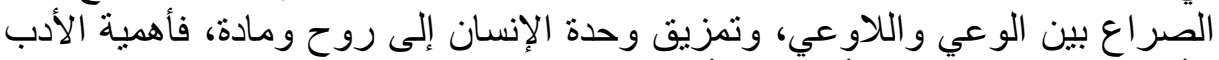

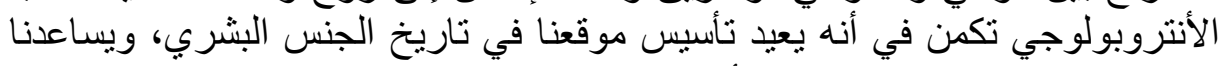

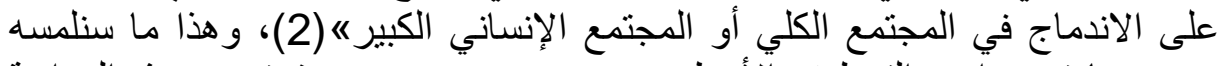

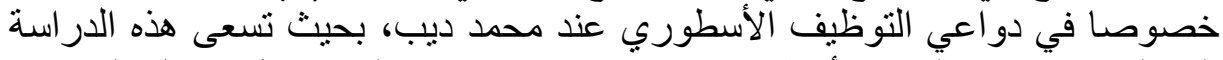

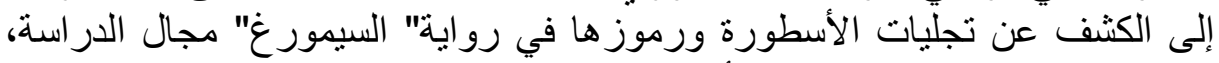

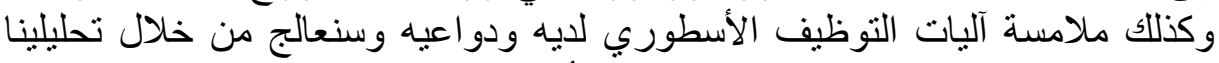

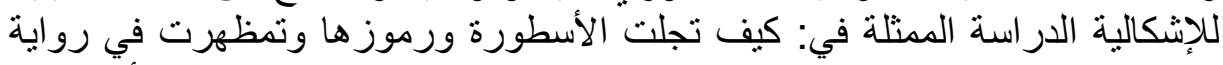

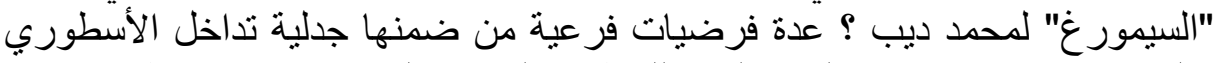

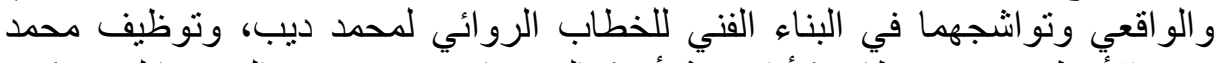

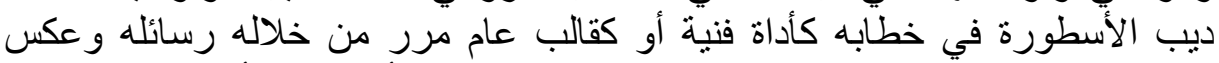

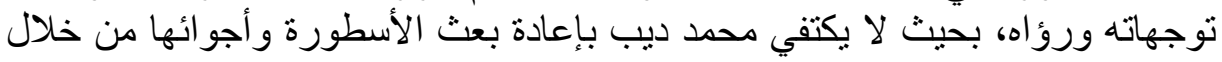

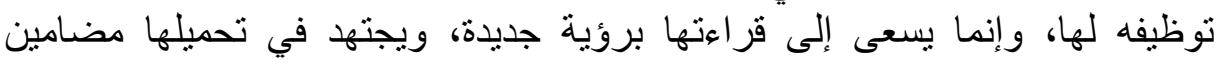

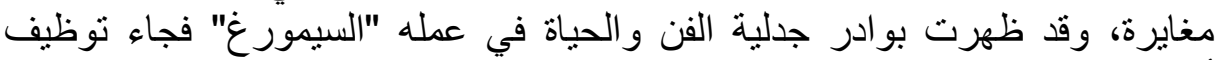
أسطورة "السيمورغ" وظيرة ليثزي هذه القضية.

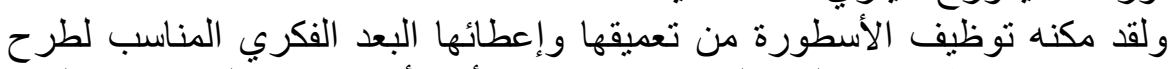

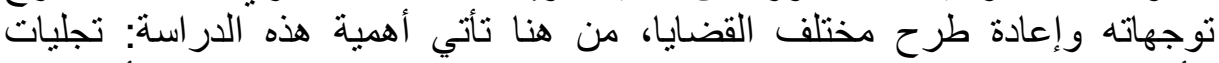

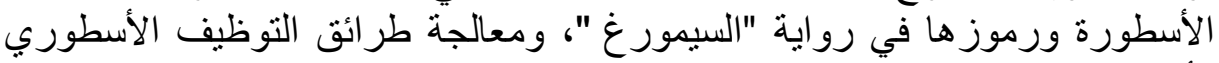

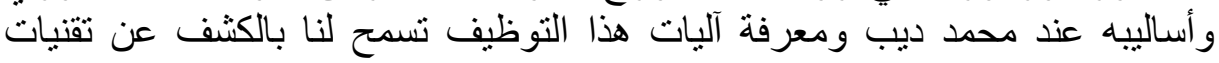

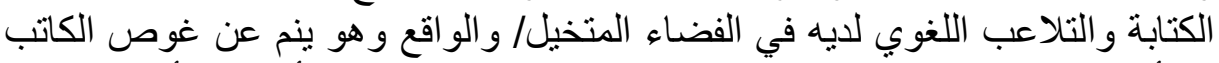

في أعماق الذات الإنسانية و الكثف عن الإبه مكامنها بو اسطة المنبع الأصلي للأسطورة. 
لغة : لا يخرج تعريف الرمز من الناحية اللغوية عن مفهوم الإنشارة والإيماء

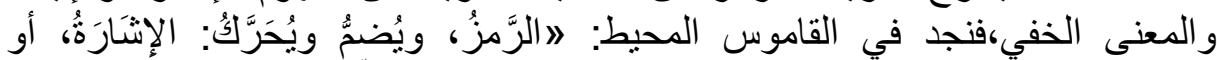

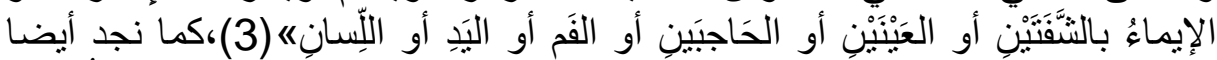

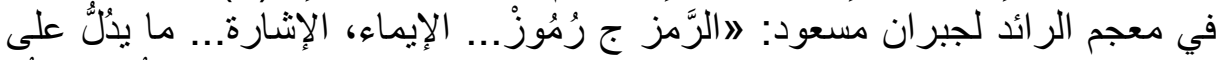

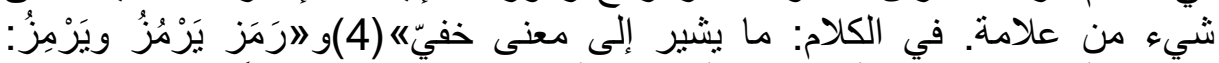

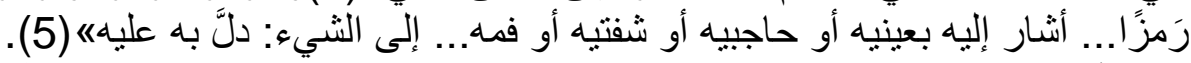

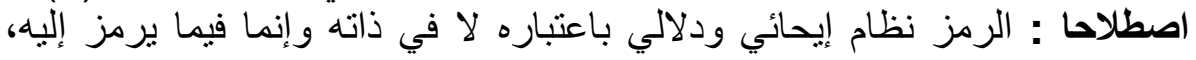

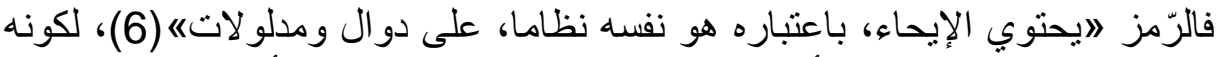

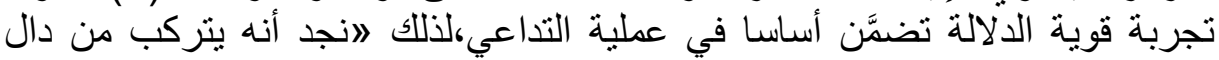

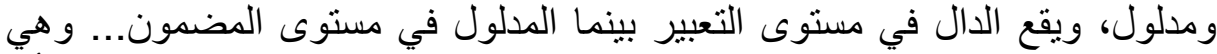

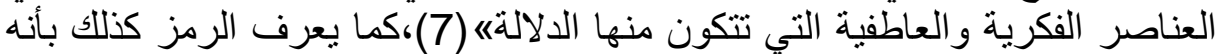

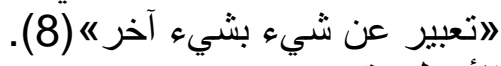

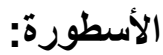

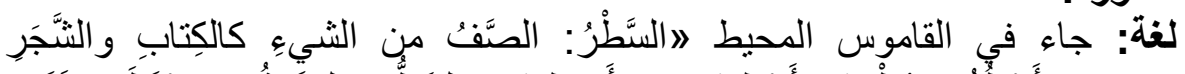

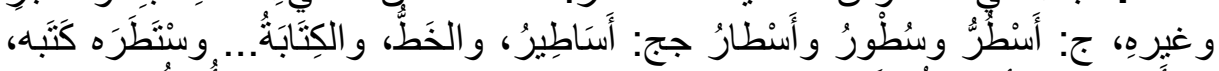

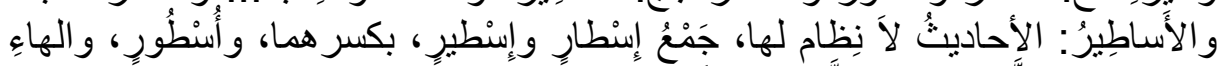

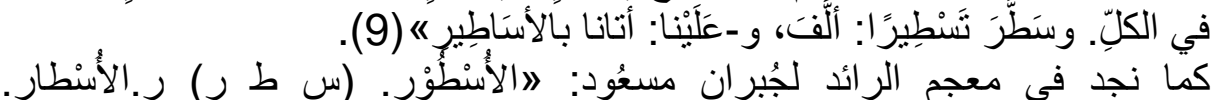

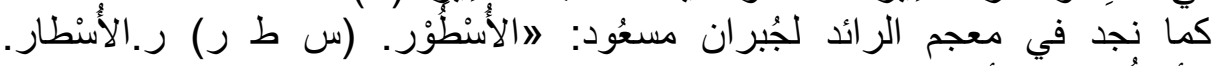

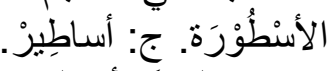
1. القصَّة أو الحكاية تمتزج فيها مبندعات الخيال بالثقاليد الثعبيّة وبالواقع.

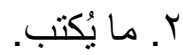

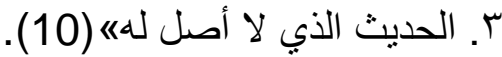

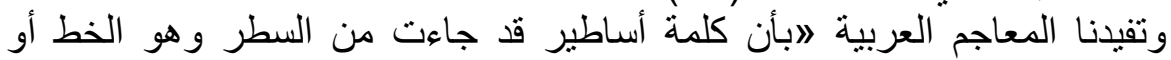

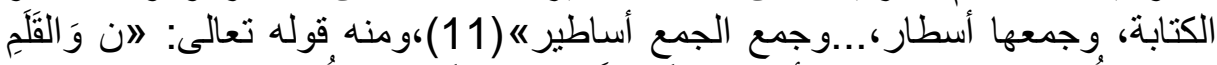

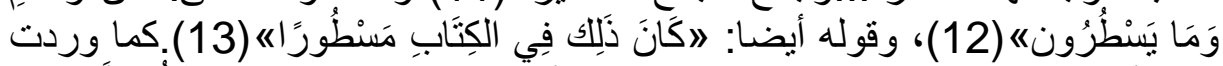

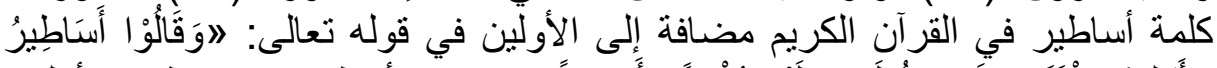

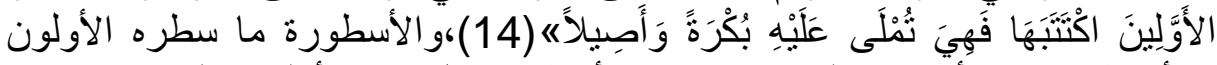
والأساطير هي الأحاديث المنمقة، ومنه فالأسطورة نقل عن الأولين و القدماء تتضمن الألئ

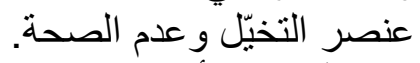
الصطلاحا: الأسطورة حكاية تقليدية وقعت في الزمن الأول فسر من خلالها الإنسان

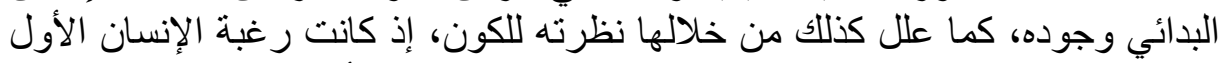

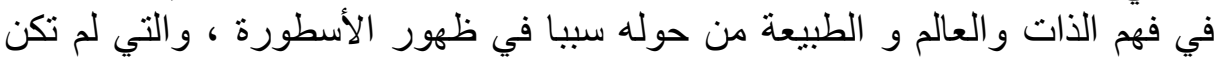

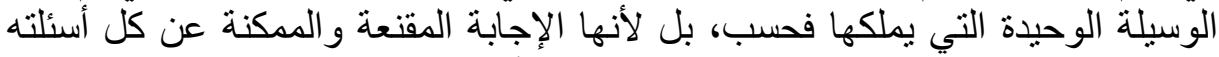

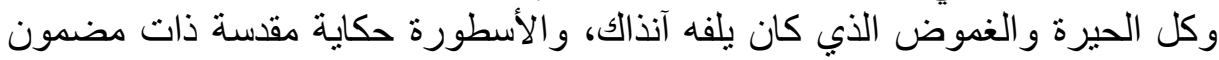

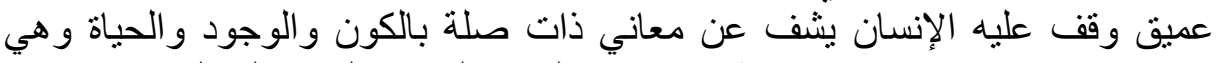

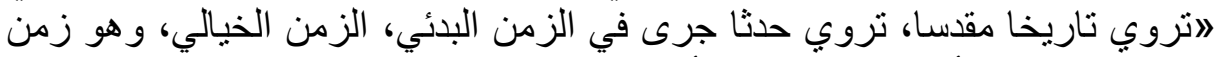

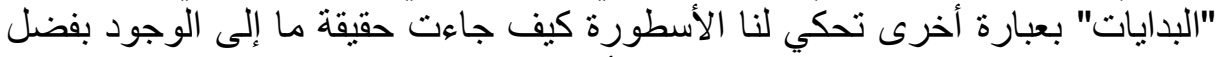

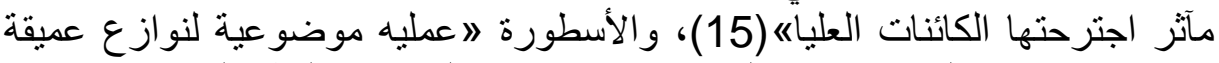

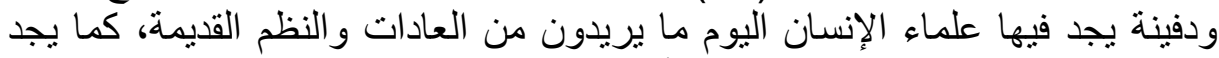

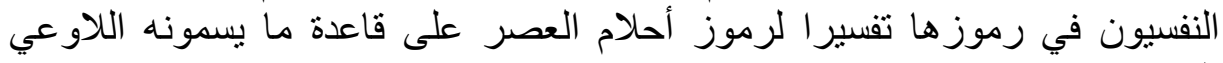

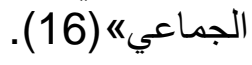


إن \ا الأساطير هي خلاصة تجارب حضارة متعددة، و حصيلة أجيال منو الية، إنها و عاء تفكير وتأمل الإنسان إزاء الطبيعة و الكون و الموت...و مظاهر القوة التي ما

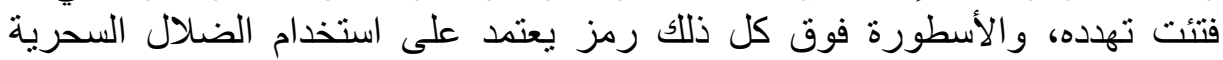

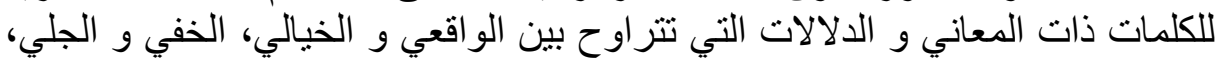

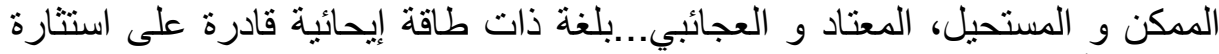

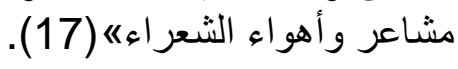

\section{III}

إن عودة الأديب المعاصر لاستتطاق الفكر الأسطوري عودة حقيقية إلى منابع الإنى الإني

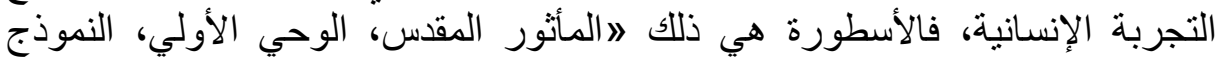

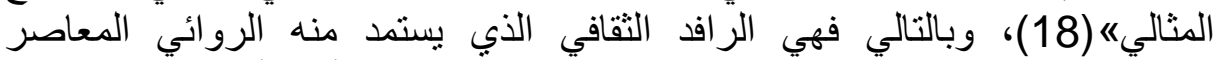

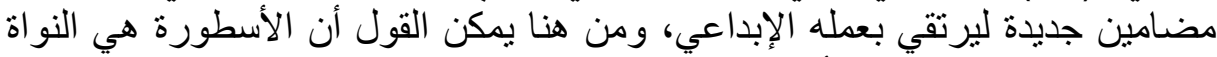

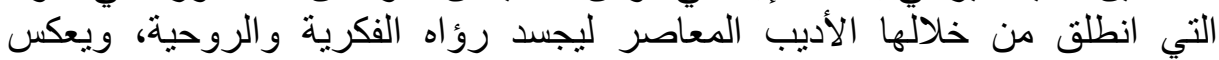

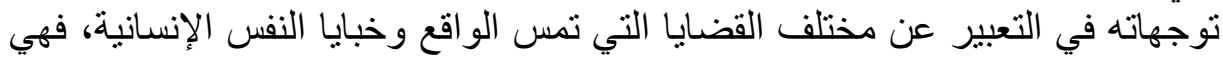

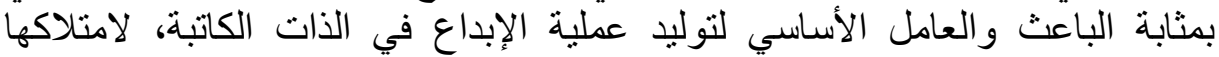

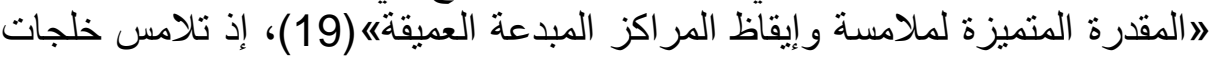

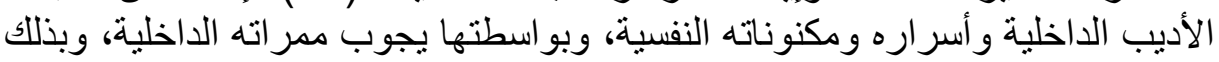

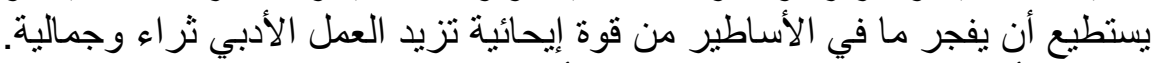

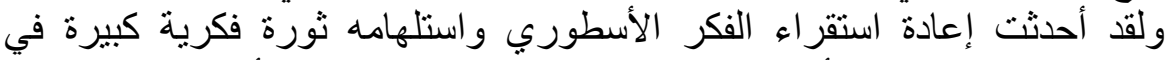

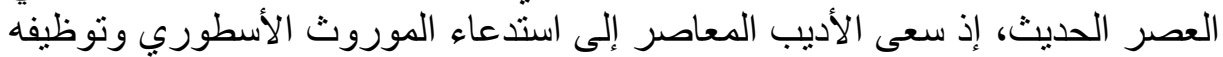

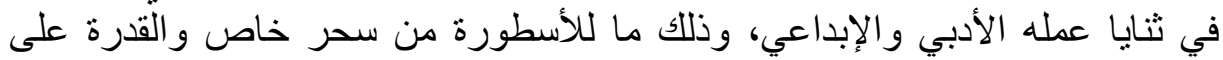

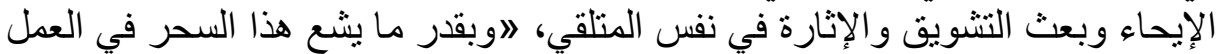

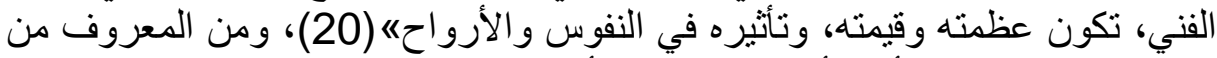

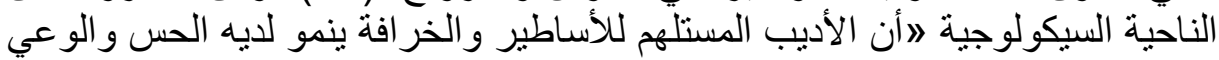

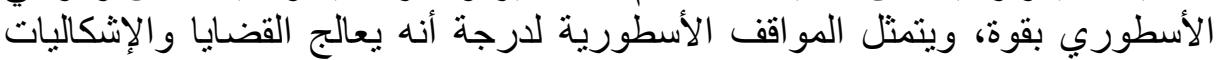

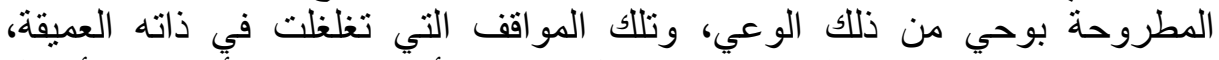

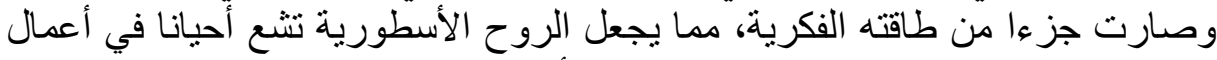

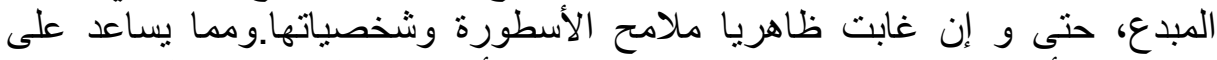

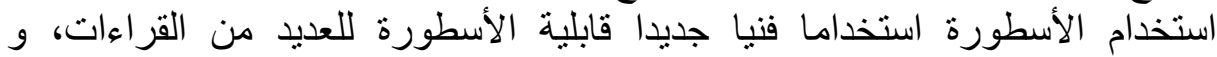
طو اعيتها لكثير من التأويلاتهورة الخغوات

IV

أغنى الأديب محمد ديب خطابه الروائي بتوظيفه للموروث الأسطوري في

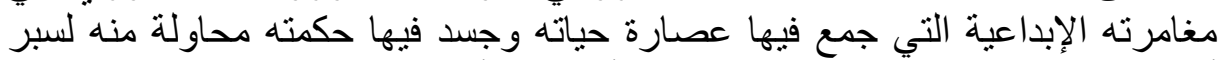

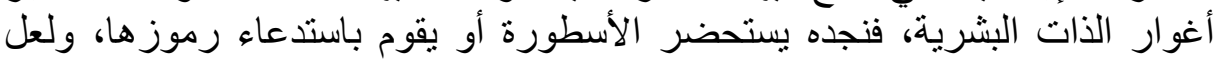

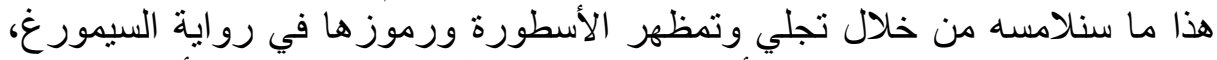

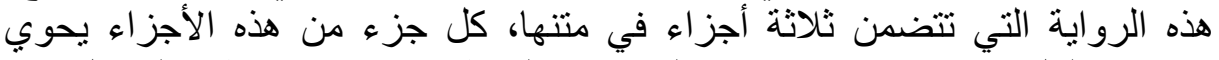

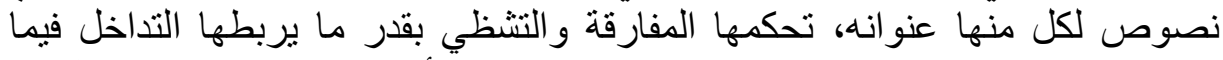

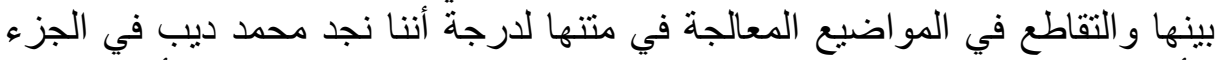

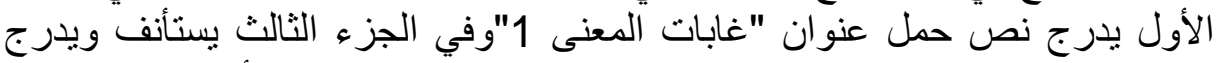

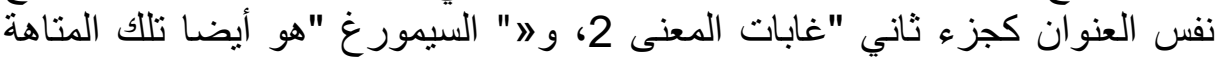


الأدبية أين يجمع محمد ديب بحيوية كبيرة بين الحكاية والقصة و المسرح و الدراسة

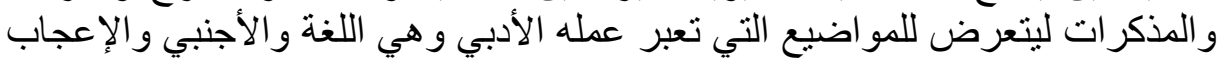

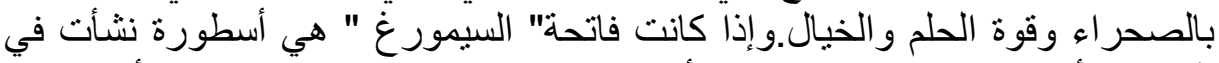

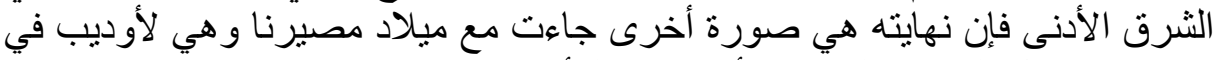

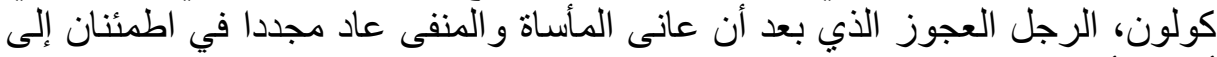

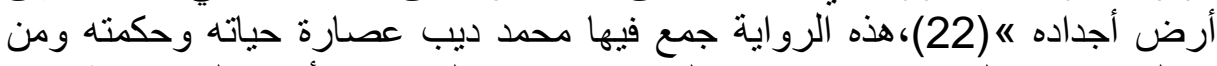

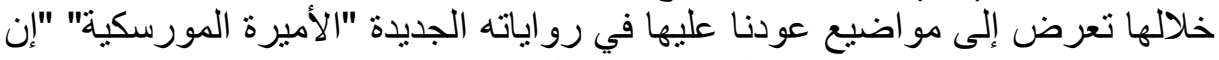
شاء إبليس" "شجرة الكلام" "مثل طنين النحل".

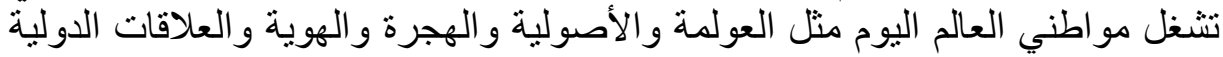

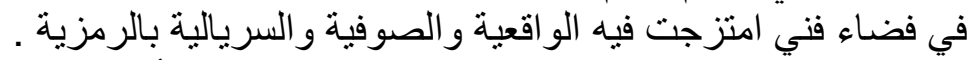

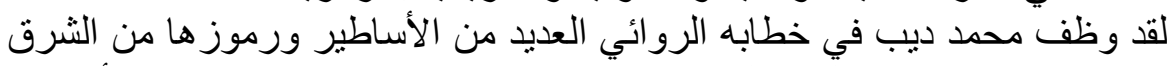

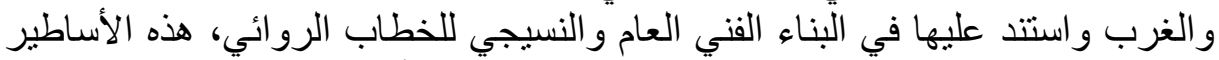

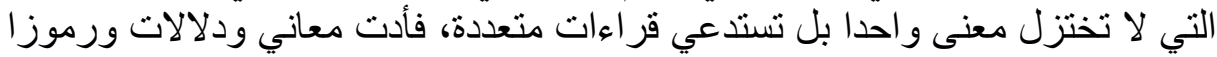

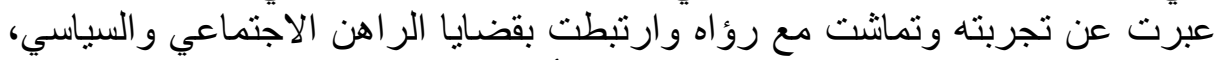

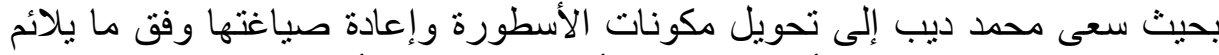

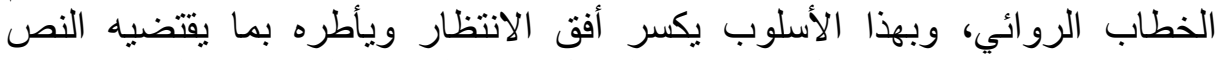

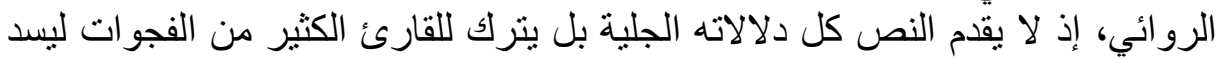

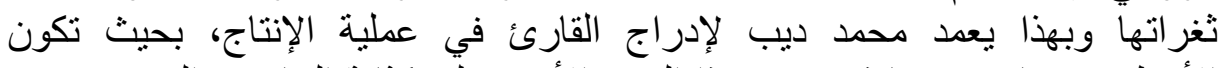

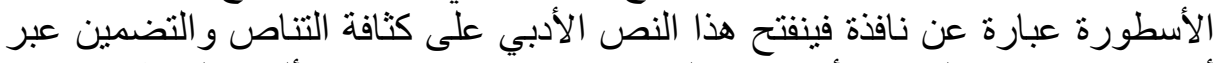

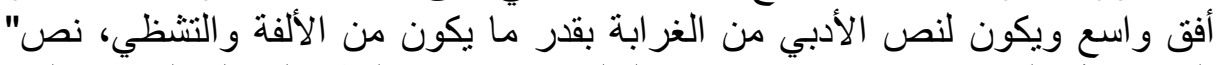

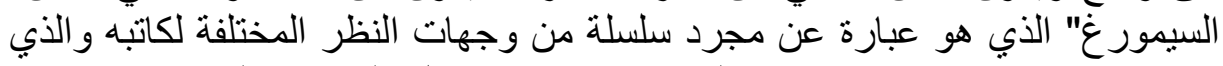

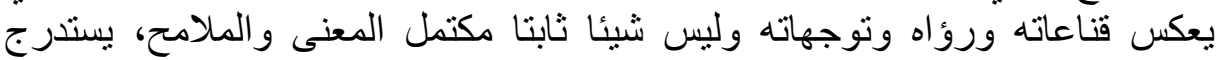

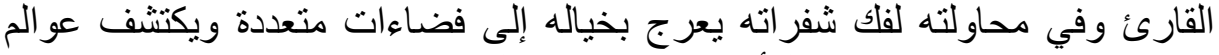

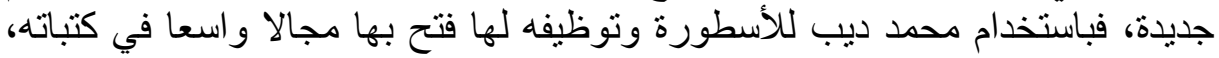

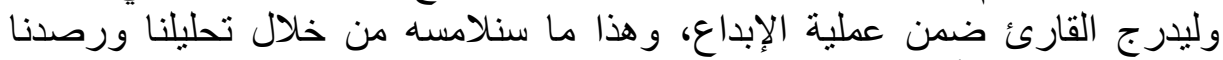

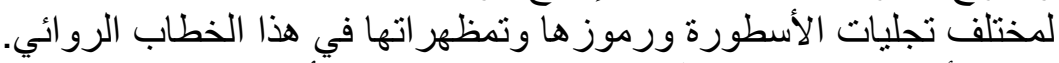

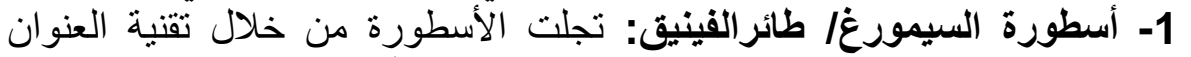

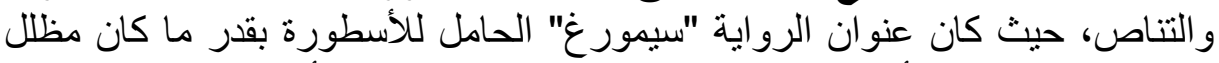

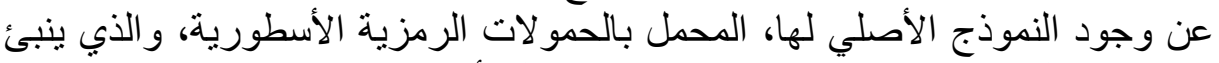

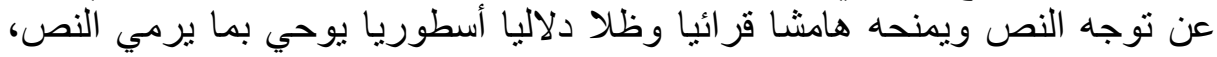

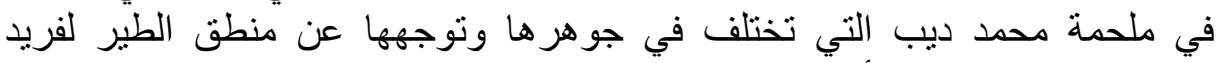

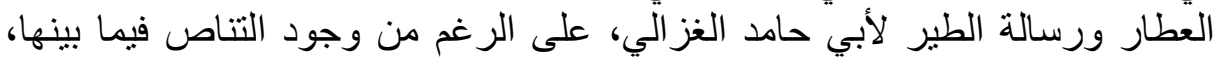

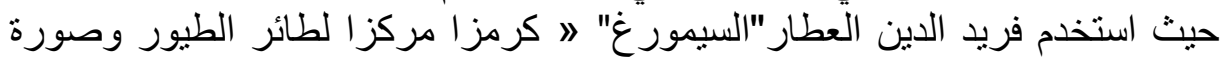

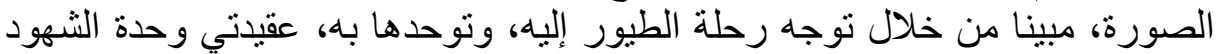

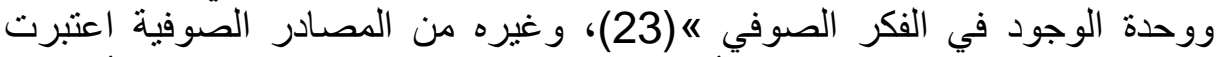

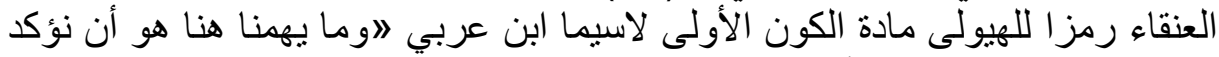

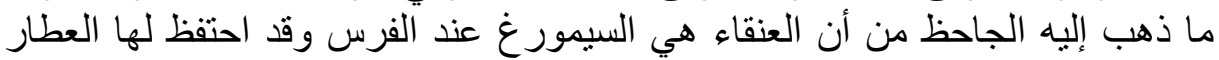

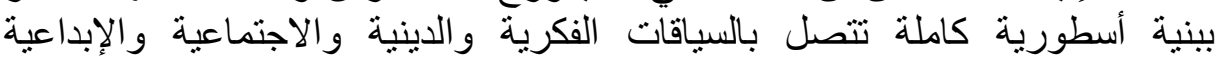

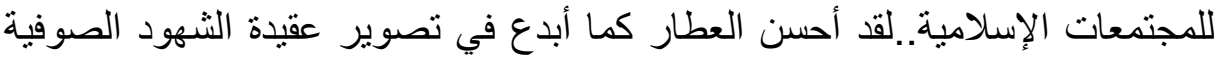

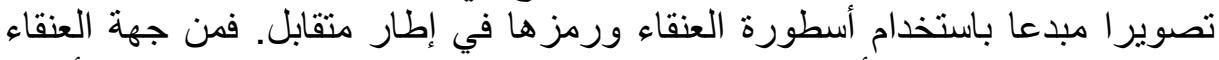

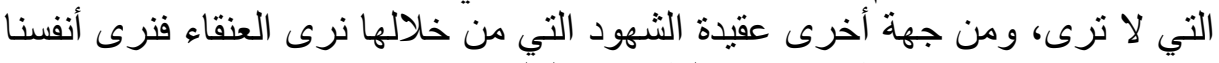

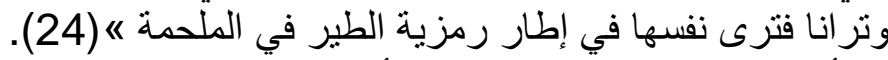

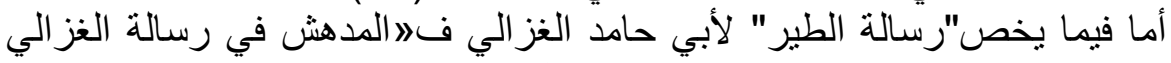

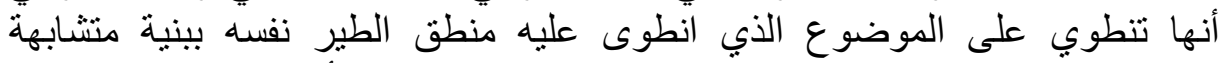
ورمزية متقاربة إلى حد التطابق وبحو افز صوفية مشتركة. إلا أن منطق الطير للعطار 
مطولة شعرية ورسالة الطير لأبي حامد الغزالي رسالة نثرية قصيرة أثببه بالمقالة.

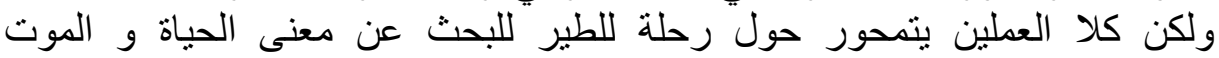

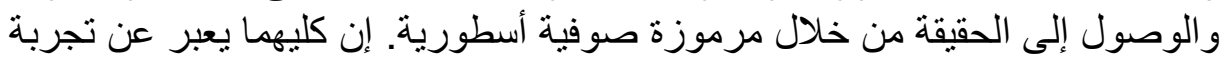

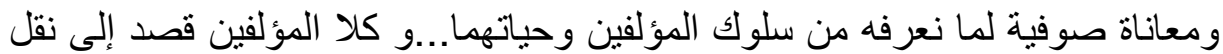

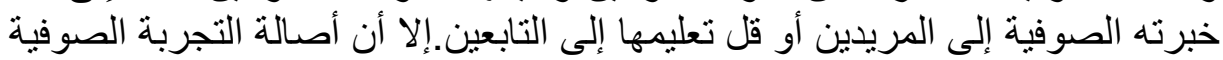

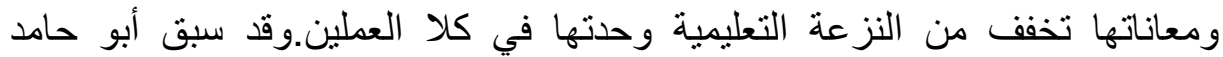

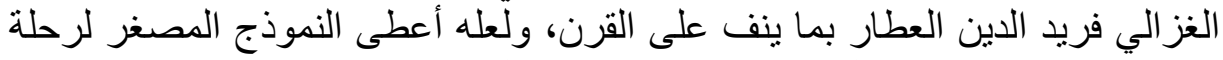

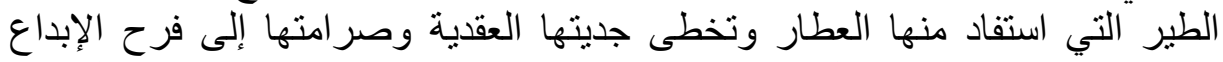

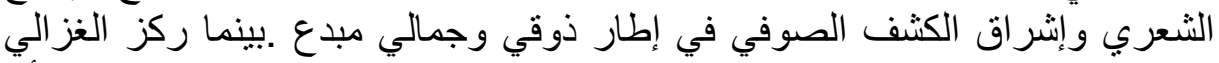

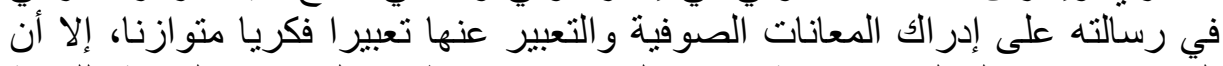

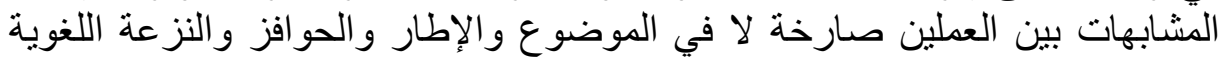

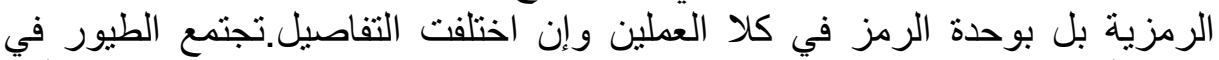

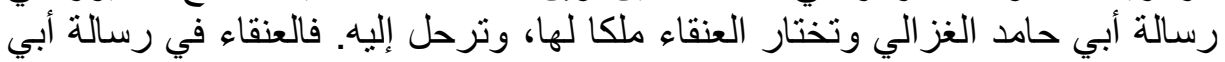

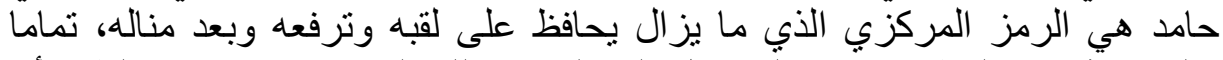

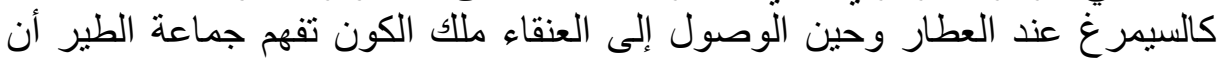

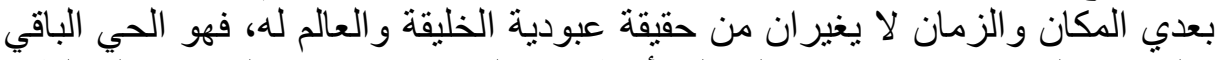

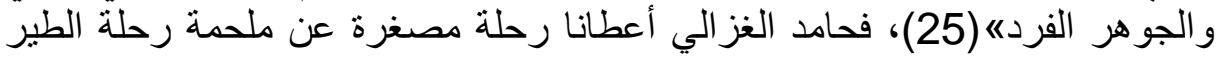

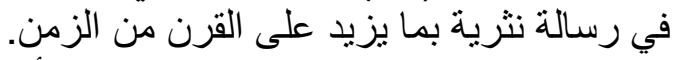

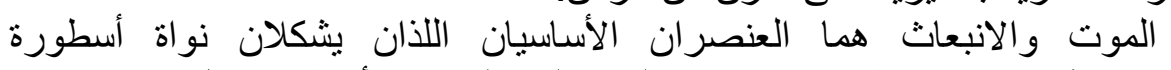

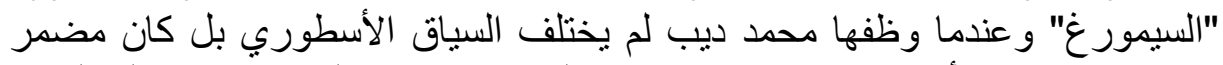

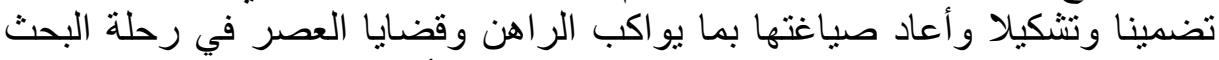

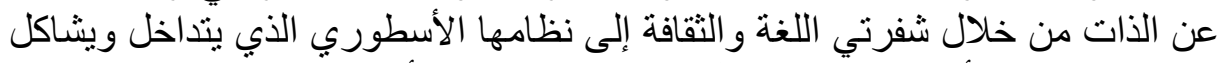

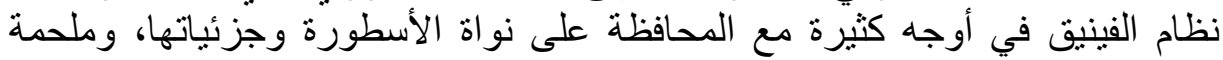

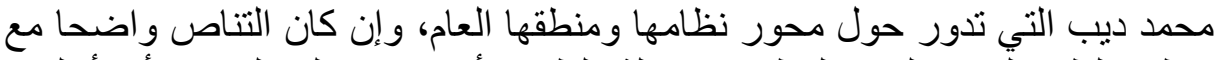

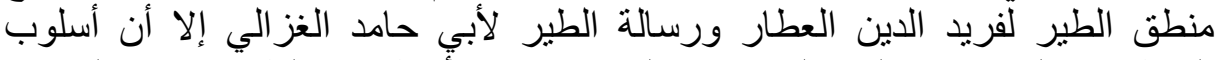

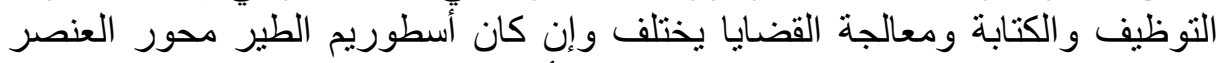

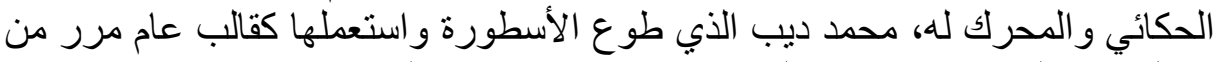

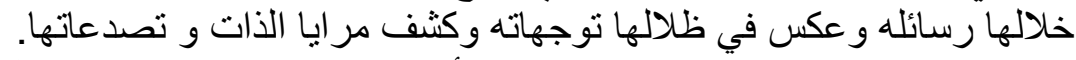

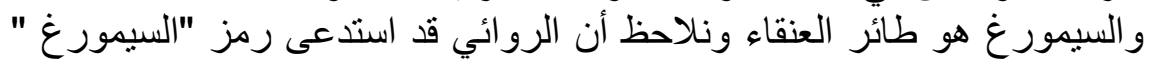

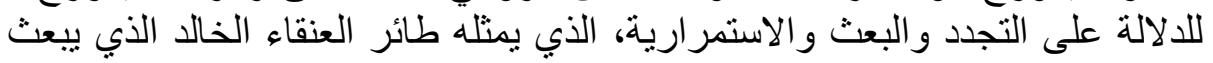

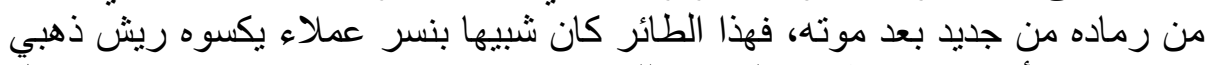

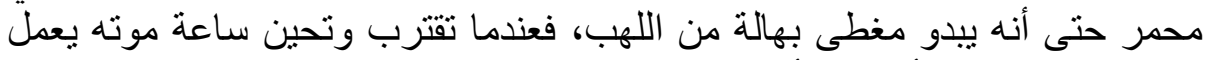

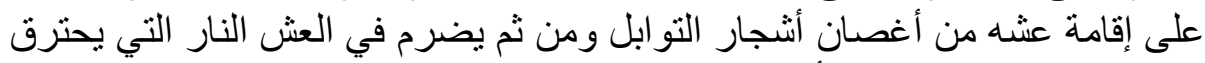

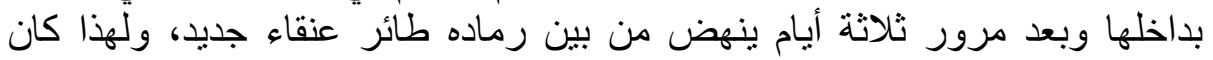

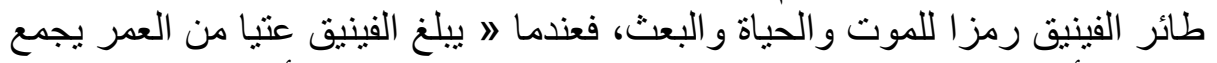

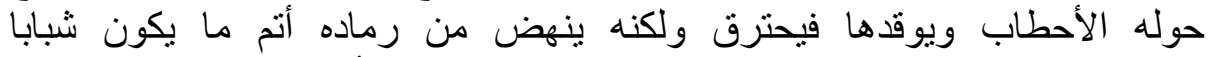

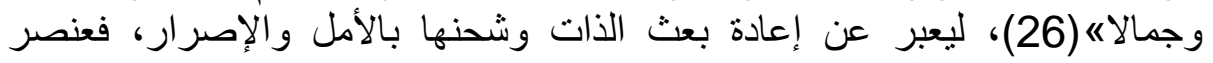

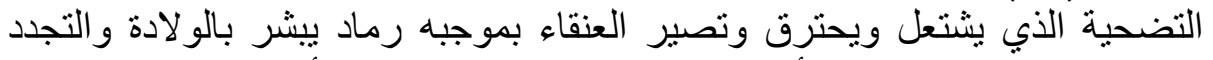

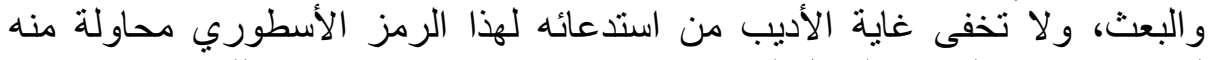

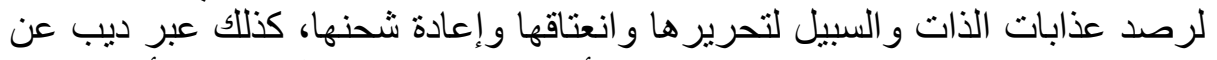

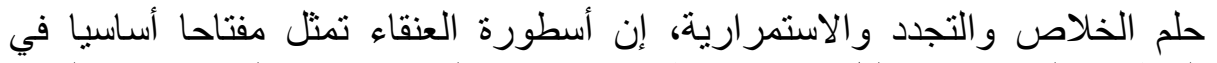

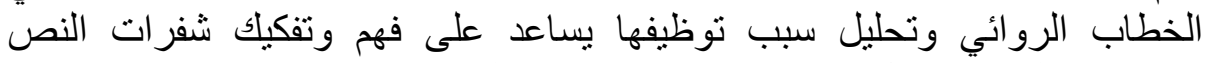

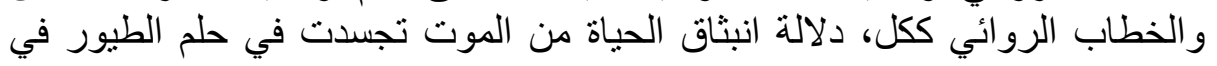


انبثاق عهد جديد تتجدد فيه الحياة ويكون مستقبلها مشرقا بعد تعيين السيمورغ ملك

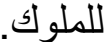

هذا النص الذي عنونه ديب " السيمورغ" يحتل فيه الفينيق مركز النبض ككل

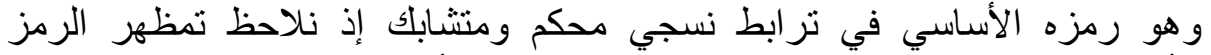

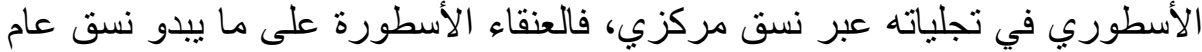

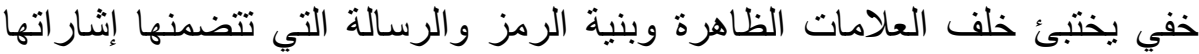

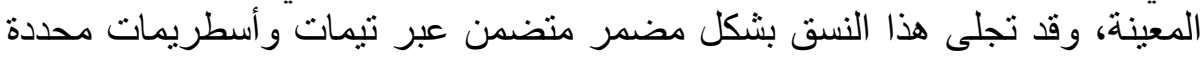

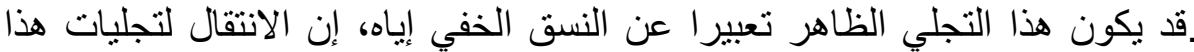

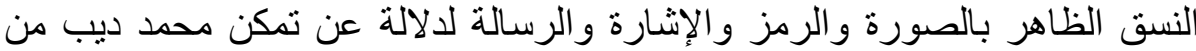

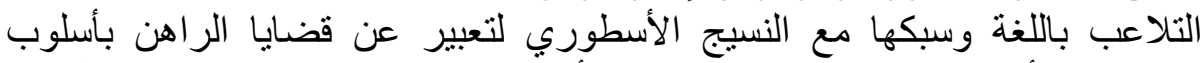

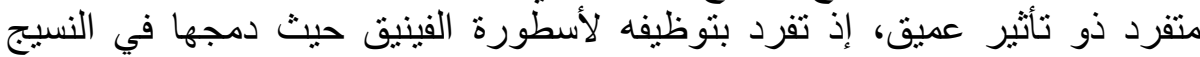

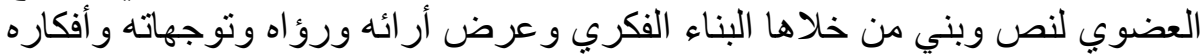

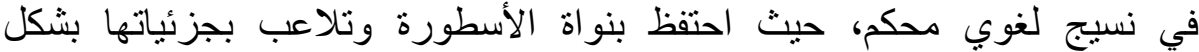

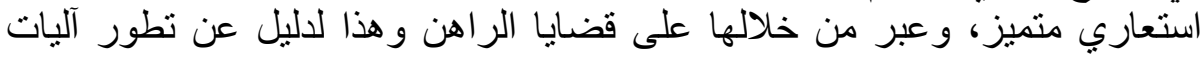

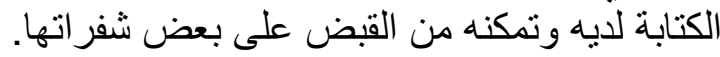

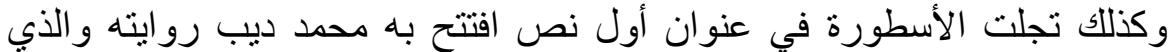

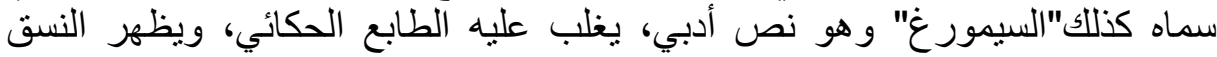

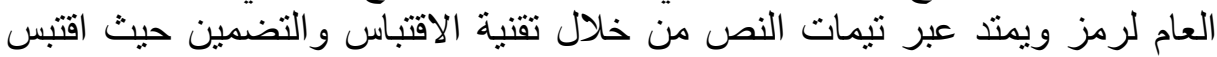

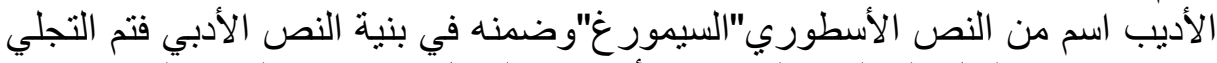

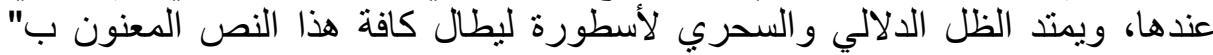

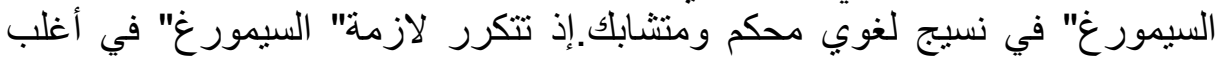

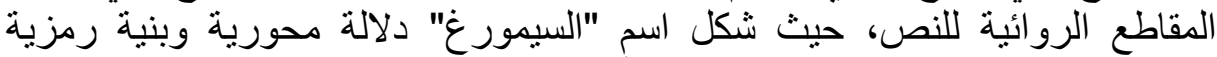

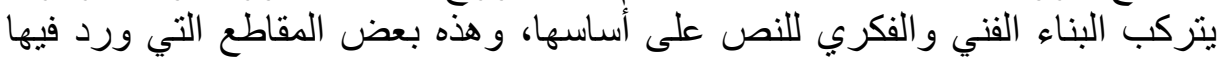

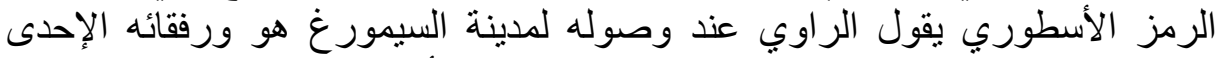

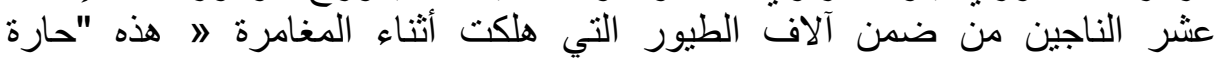

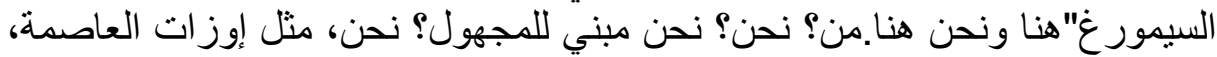

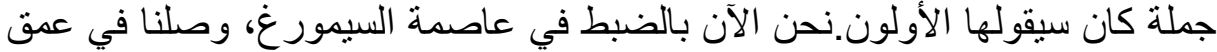

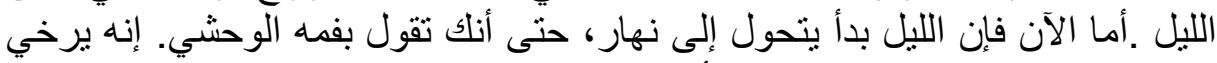

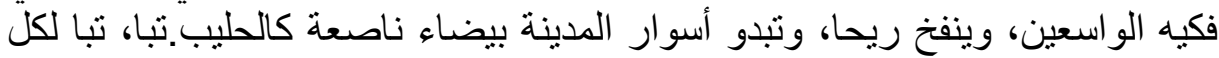

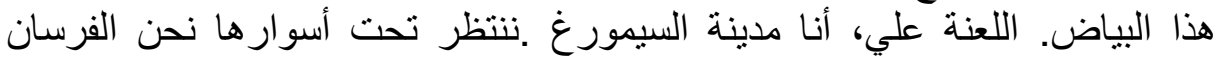

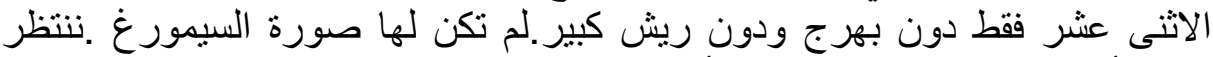

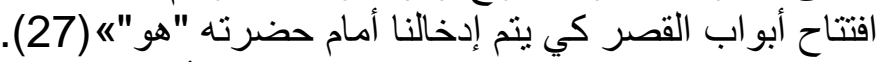

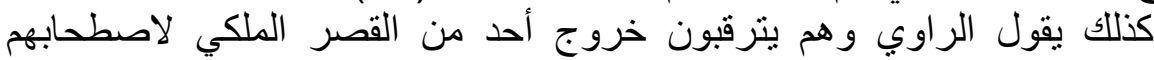

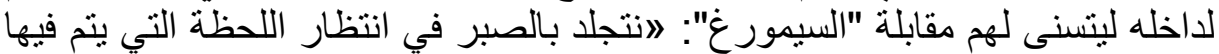

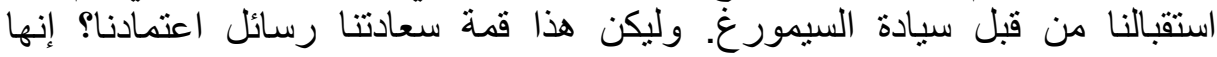

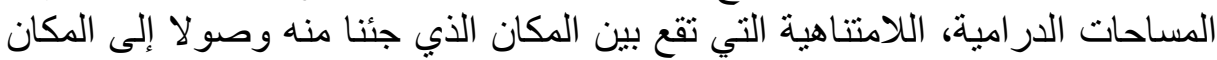

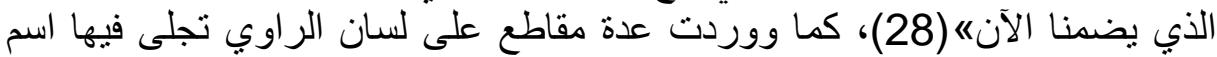

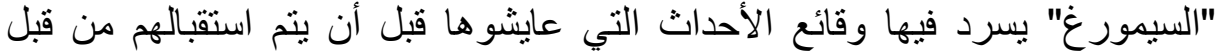

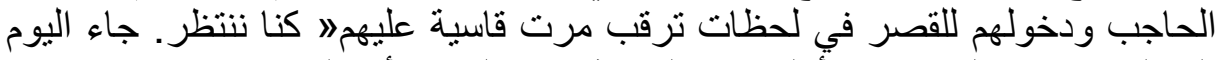

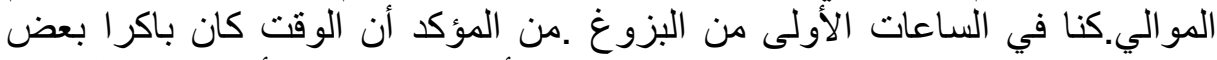

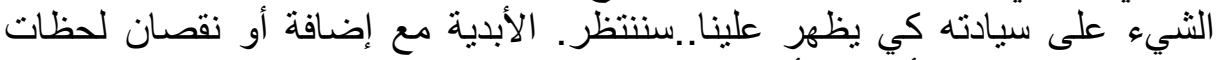

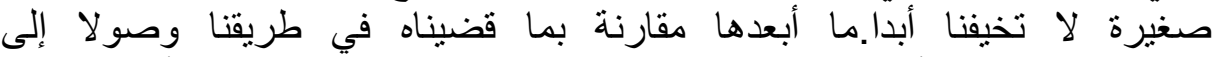

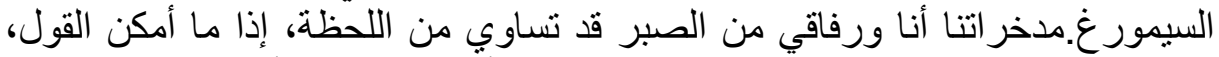

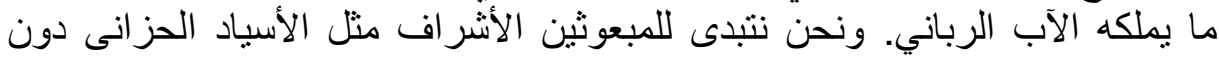

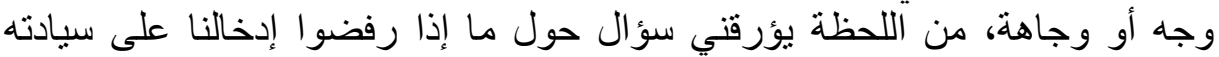


رغم المساعدة التي قدمها لنا الوسطاء المتفهمون لتوسلنا، الويل لنا إذا ما تم التأكد من

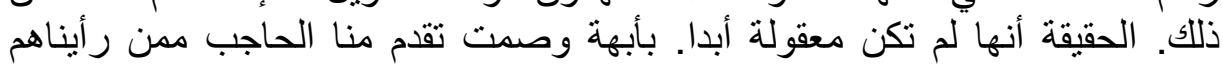

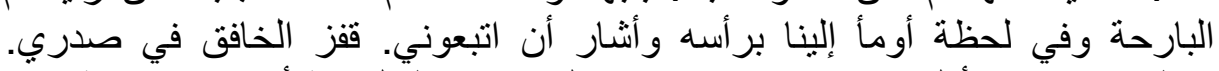

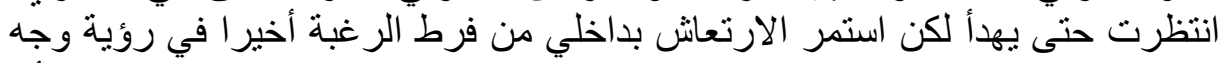

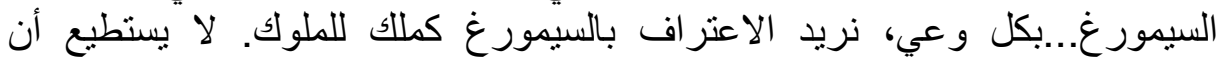

يرفض لنا هذاع(29).

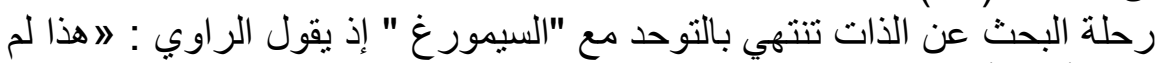

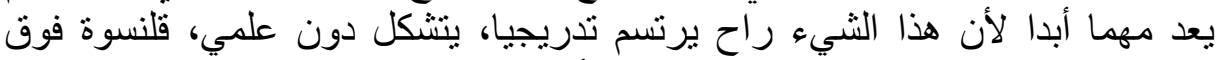

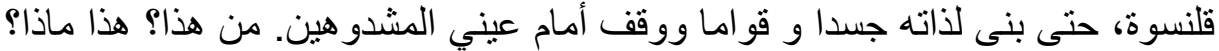

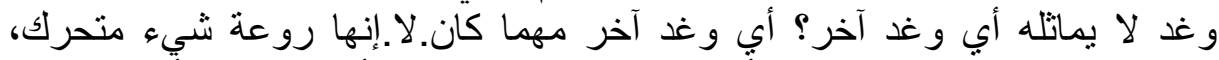

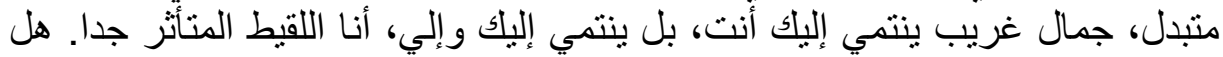

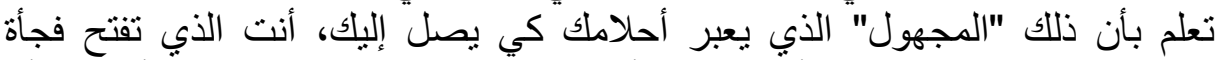

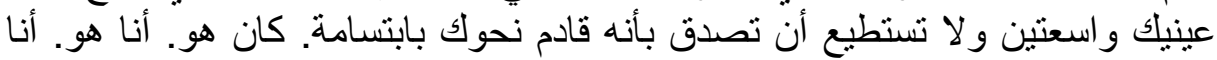

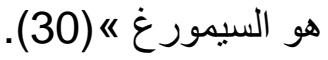
وفي هذا المقطع الذي يقول فيه الراوي لاأنت الذي التقطك التاريخ في طريقه

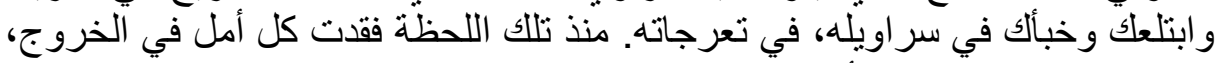

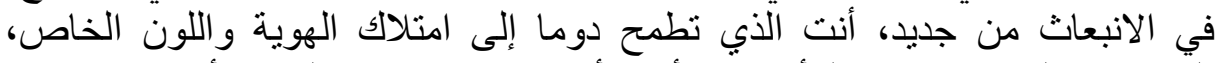

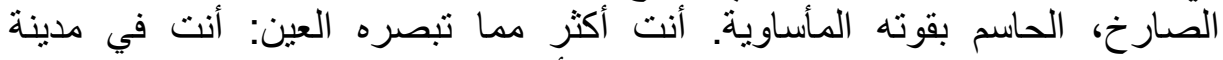

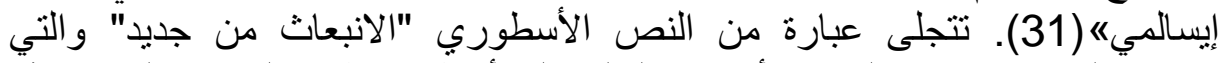

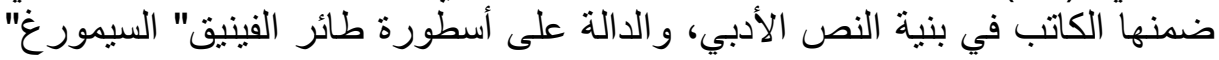

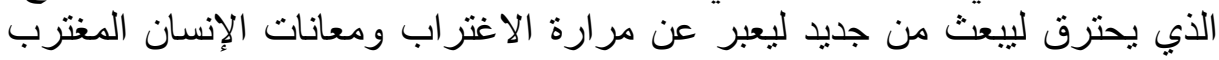

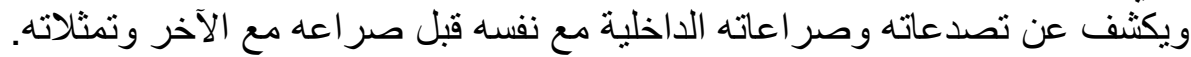

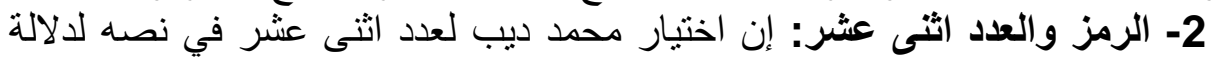

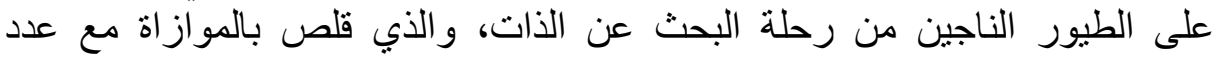

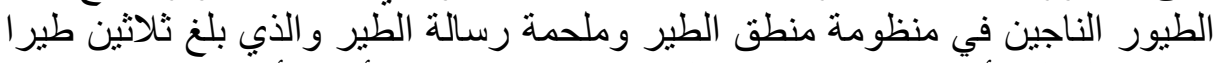

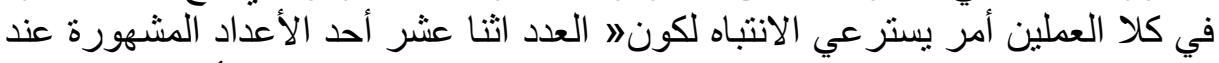

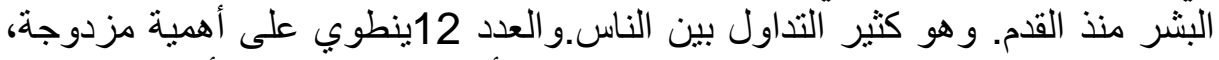

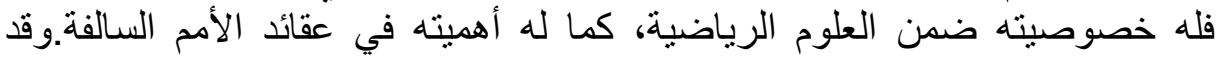

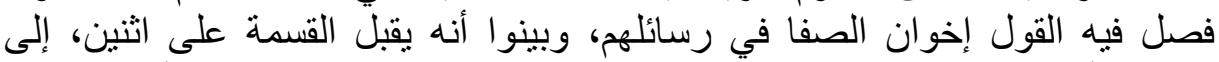

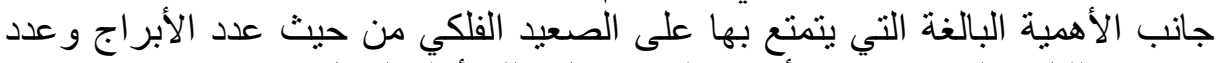

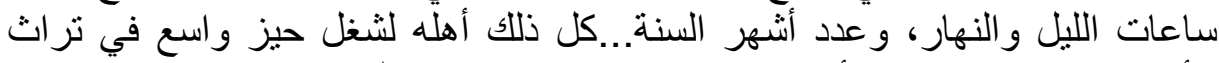

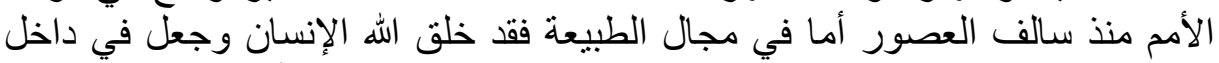

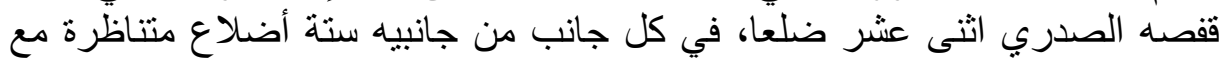
مثيلاتها.كذللك عدد فقرات الظهر عند الإنسان 12فقرة)《(32).

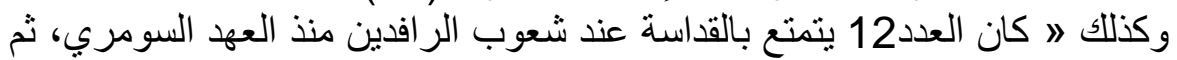

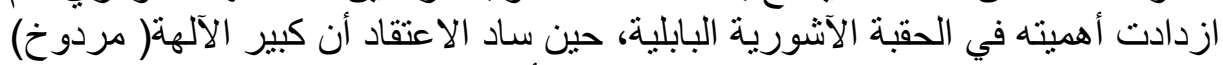

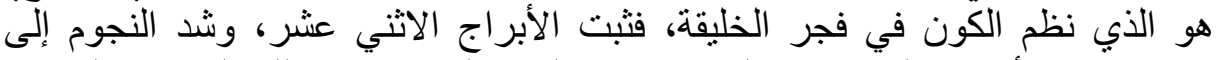

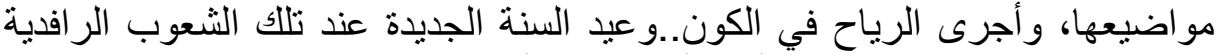

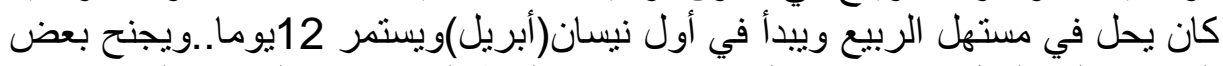

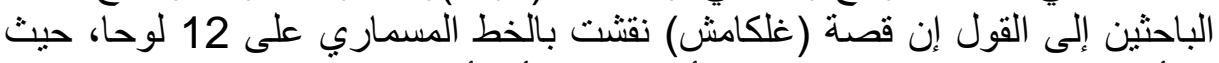

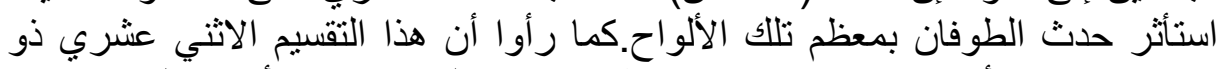

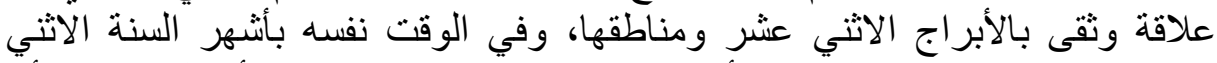

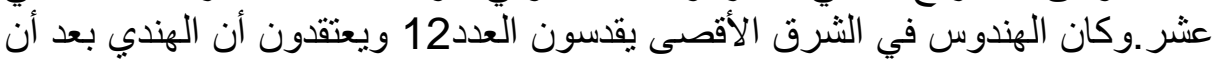


يموت ويدفن ترتفع روحه إلى السماء بعد اثني عشرة سنة.وربما كان ذللك أيضا مرتبطا بمفهوم الأبراج الاثني عشر ووفي الميثولَوجيا الإغريقية يتكون مجمع الآلهة

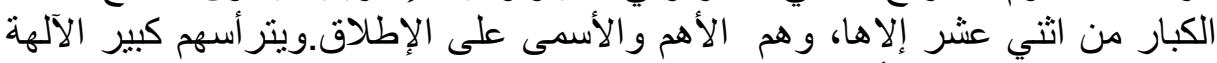

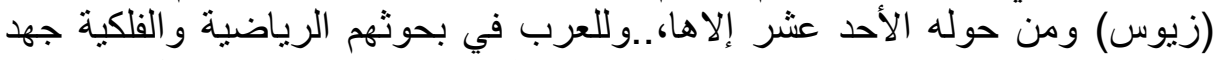

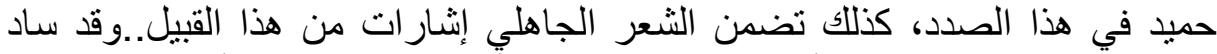

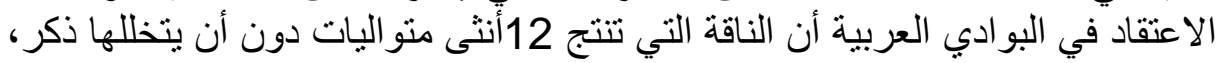

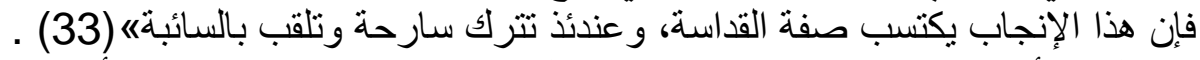

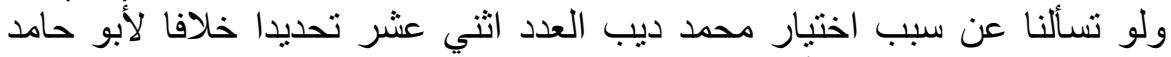
الغزالي والعطار ، وهو عدد أصغر بكثير من العدد الذي اختي اختاره العطار في منظومتئه

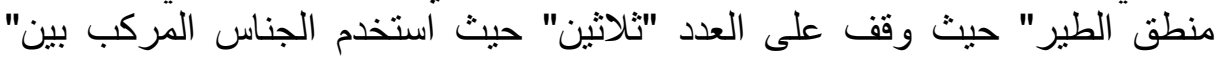

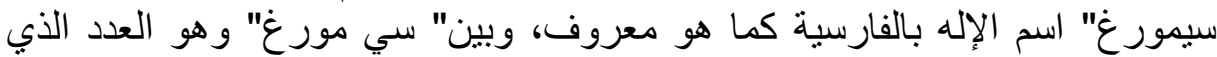

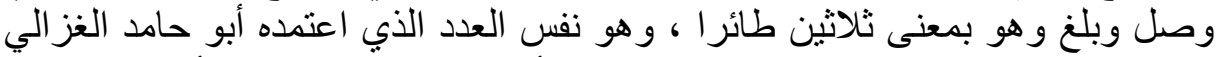

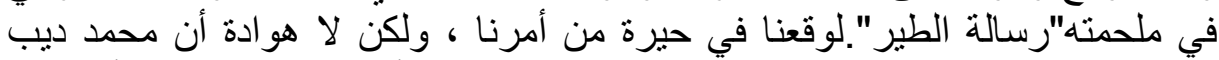

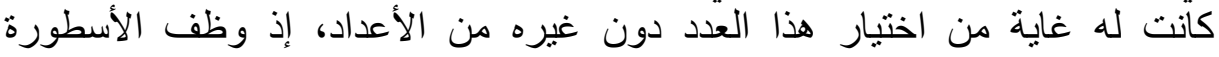

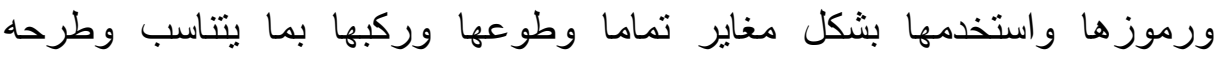
و ونطلقات تفكيره ورؤيتها.

ولا عجب أن يتخذ من العدد 12رمز السناسيا في نصاه و الذي يتو اشج مع أسطورة

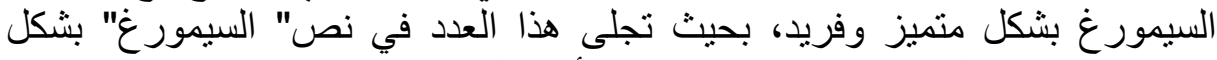

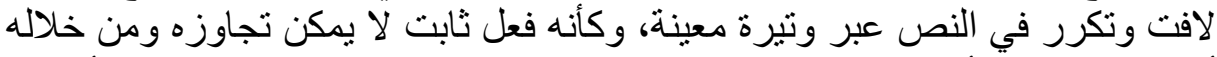

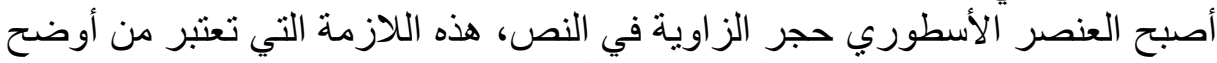

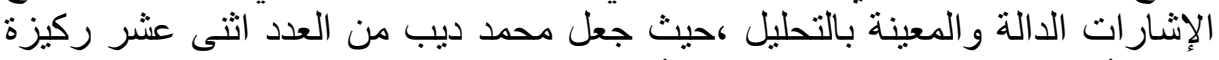

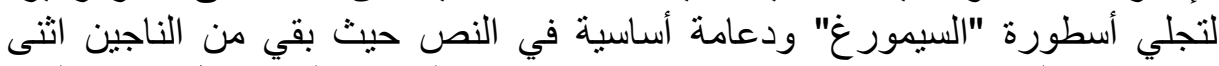

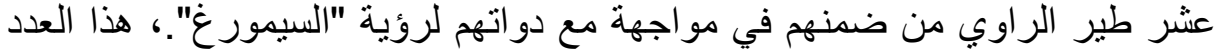

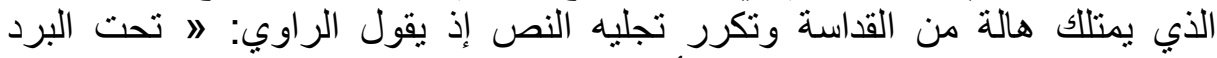

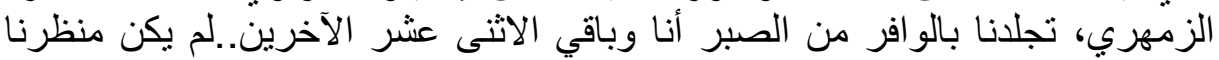

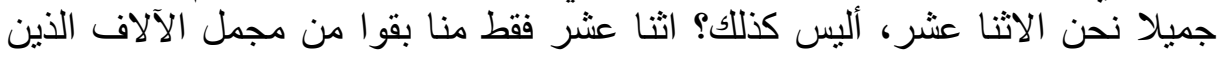

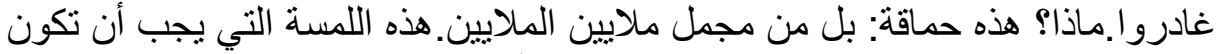

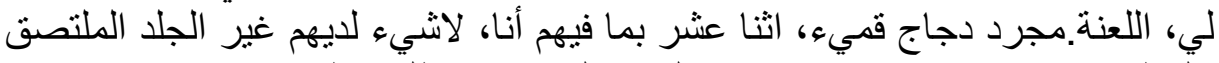

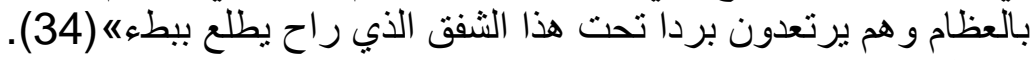

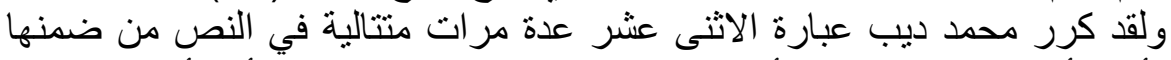

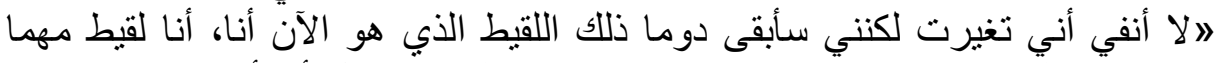

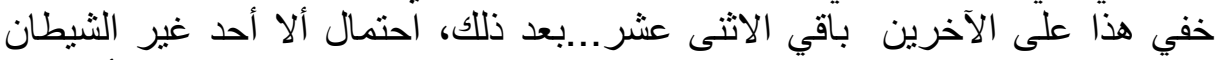

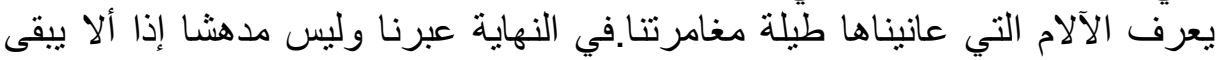

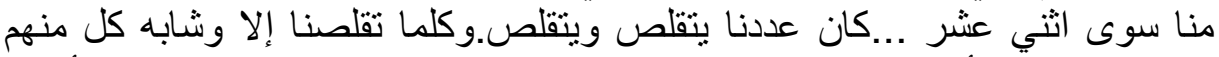

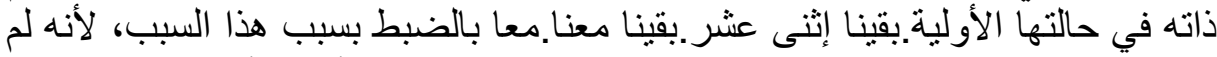

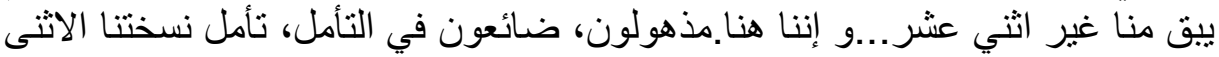

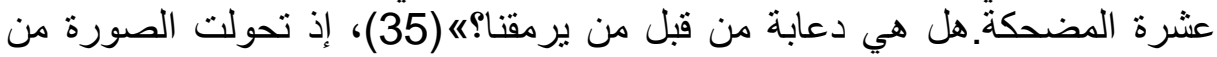

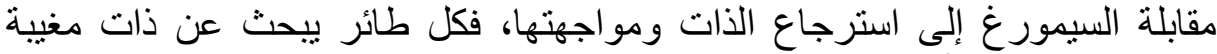

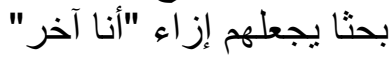

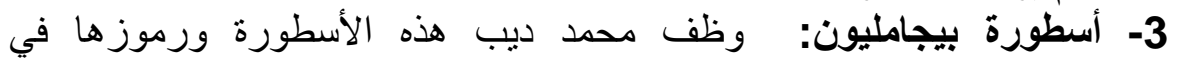

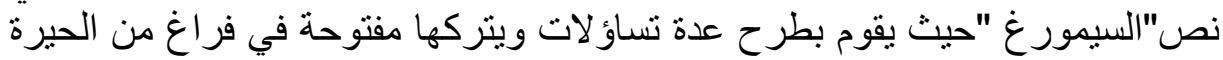

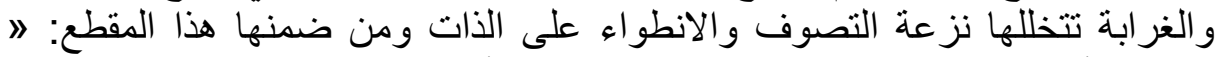

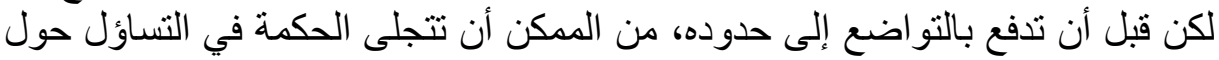

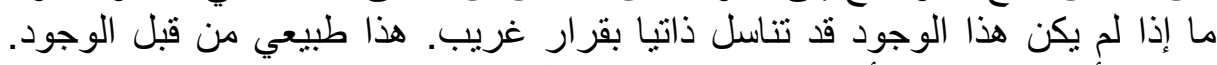
الحقيقة أنك على علم بأن هذا الثيء قد فل حصل على على العلم والضمير من لدن حكيم 
عارف، الحقيقة أنه يشبه بيخماليون المثير للشفقة إذا ما وجد وتللك حكاية أخرى، هذا

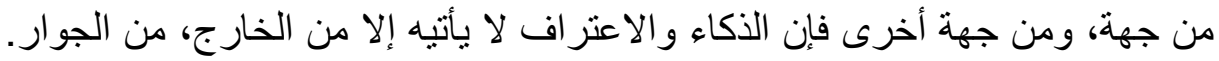

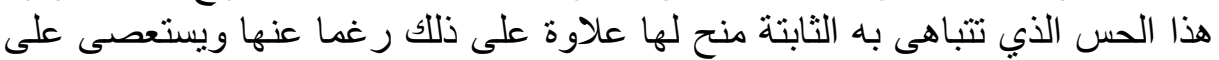

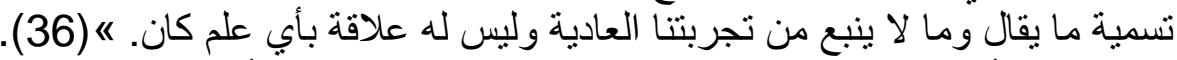

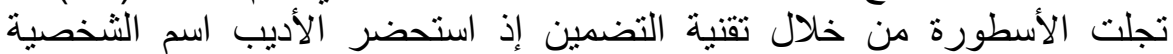

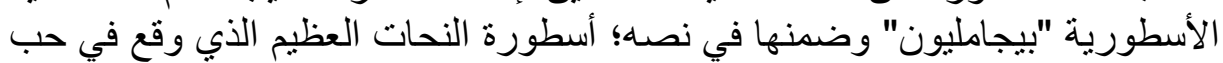

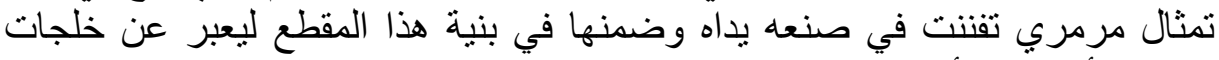

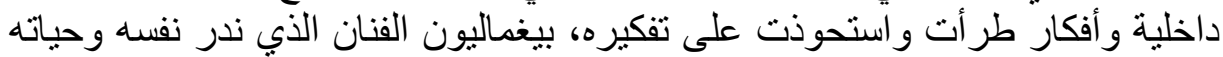

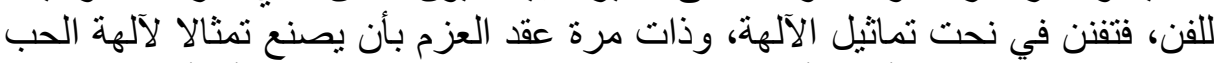

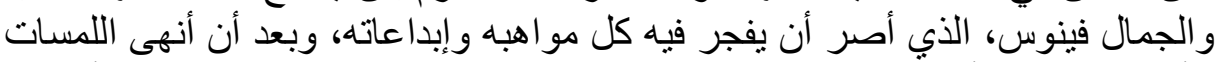

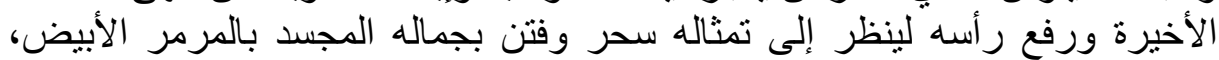

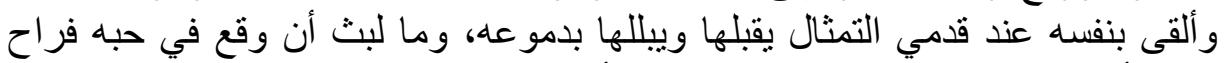

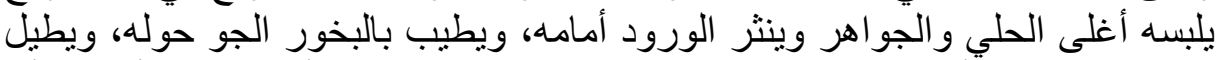

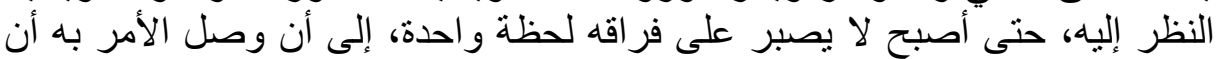

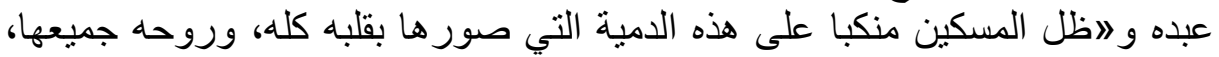

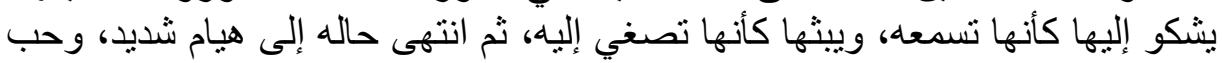

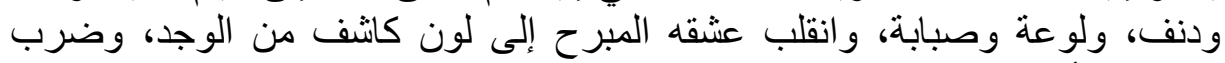

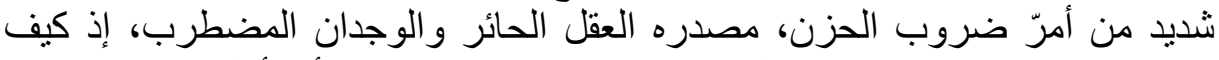

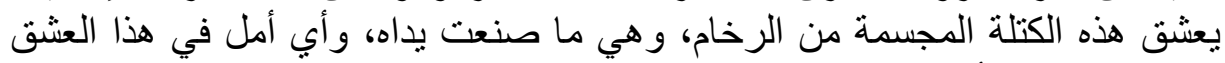

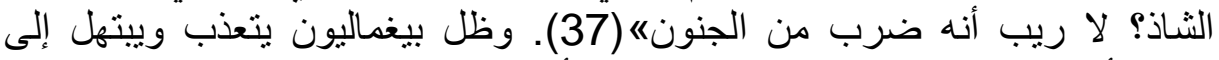

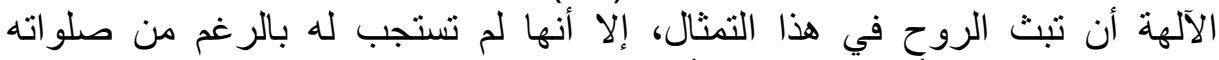

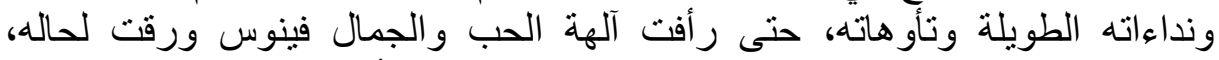

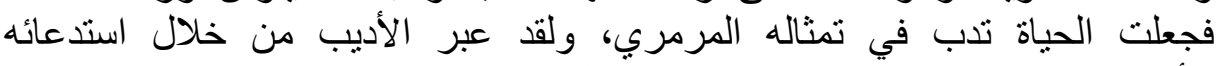

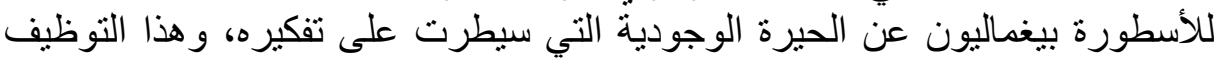

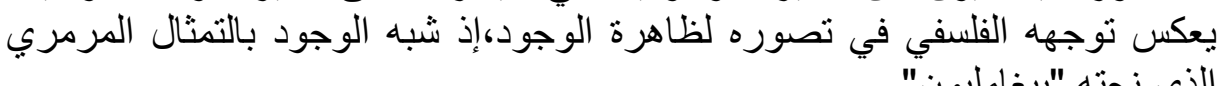
4- أسطورة الخطيئة الأولى"السقوط من جنة عدن": تجلت الأسطورة في

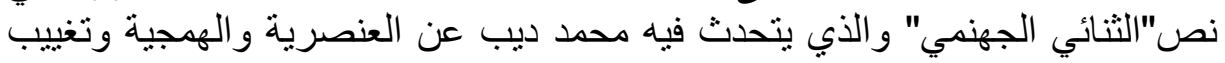

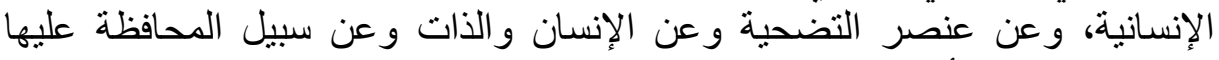

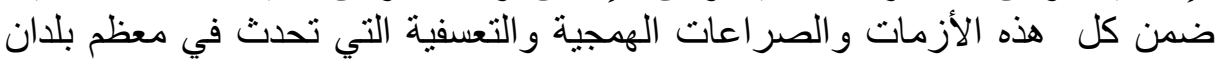

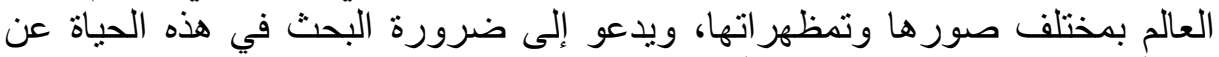

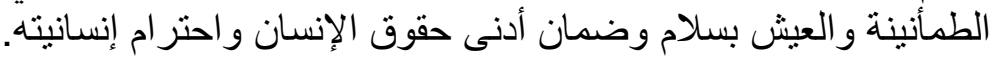

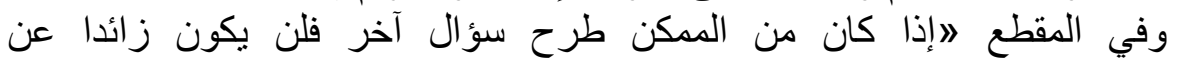

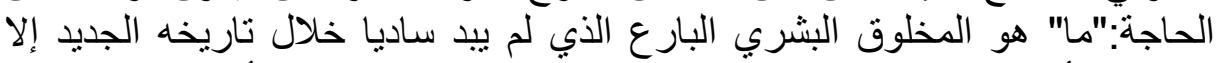

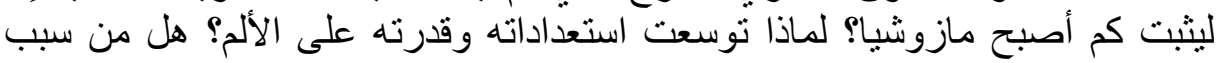

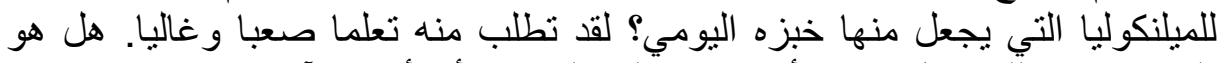

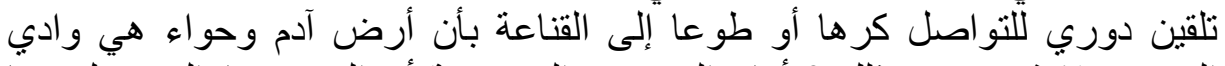

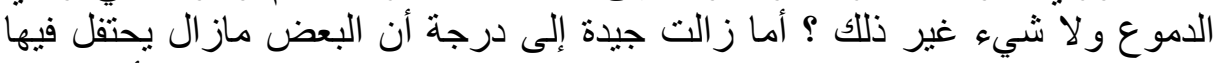

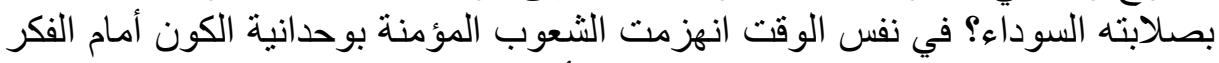

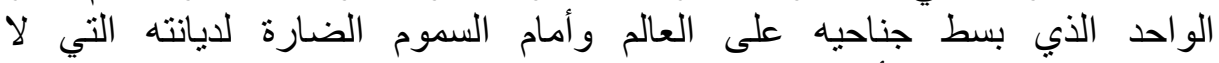

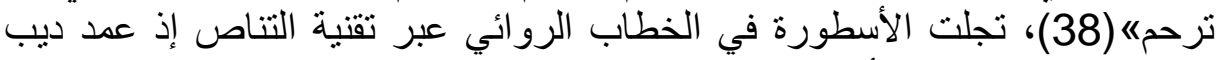

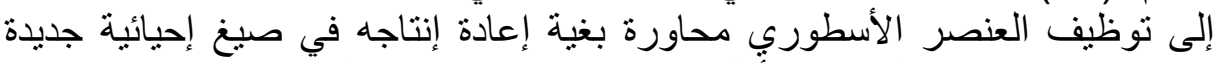
مختلفة عن توارده التراثي الأول، إذ عبر ديب من خلال توظيفه إعذأ لهذا العنصر 
الأسطوري عن حقيقة مأساة ابن آدم على الأرض و بأن أرض أدم أعدت الثقاء لا

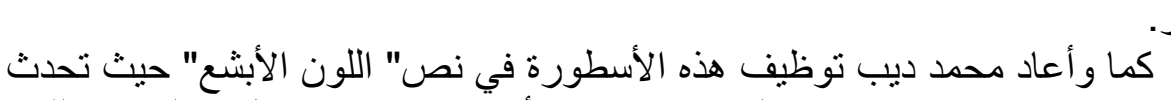

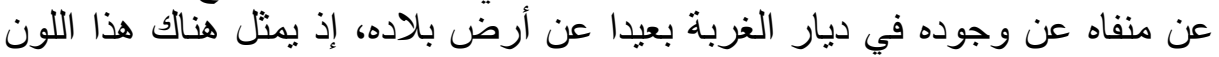

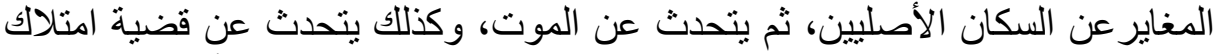

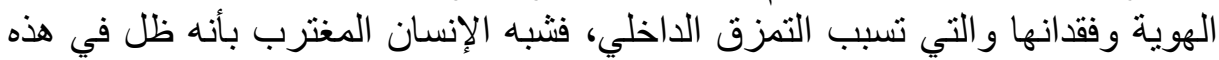

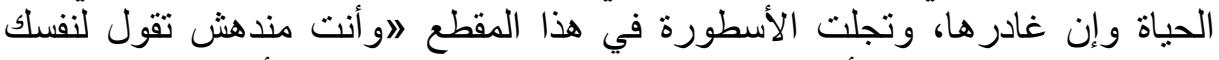

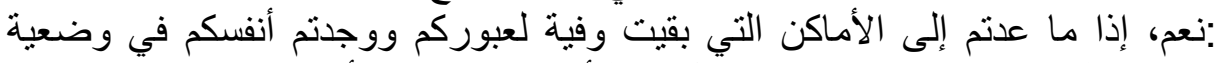

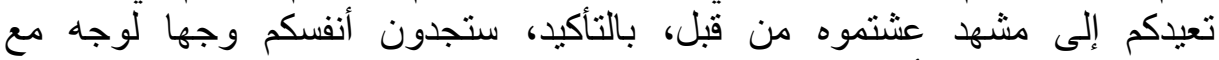

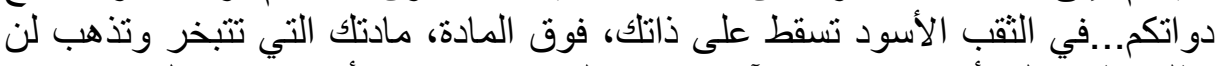

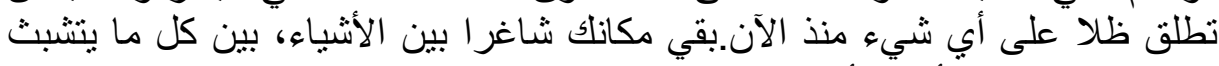

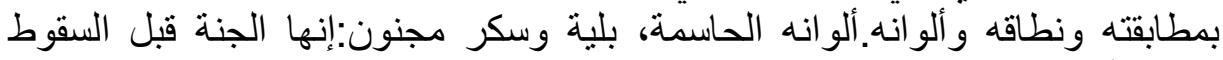

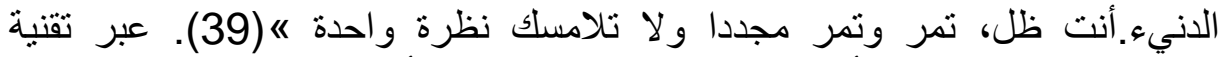

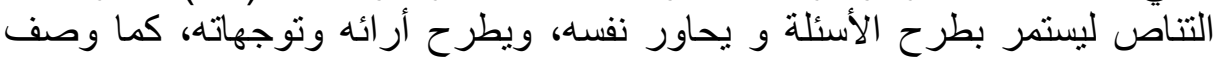

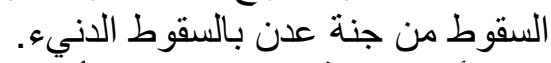
5- أسطورة فينوس: تجلت الأسطورة النئ عبر تقنية التناص كما نلمس ذلك في نص

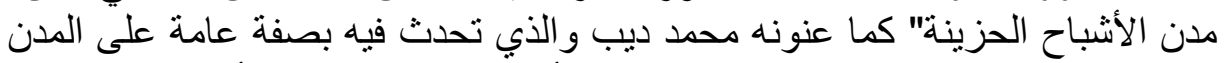

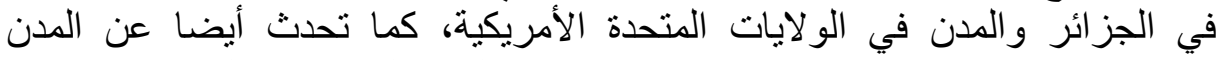

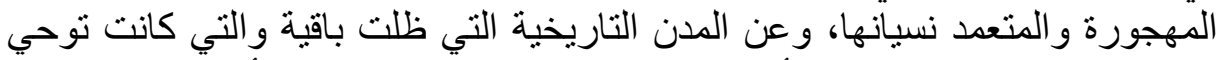

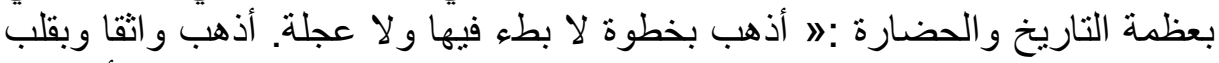

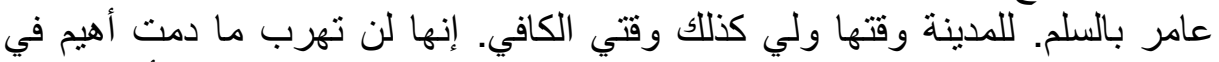

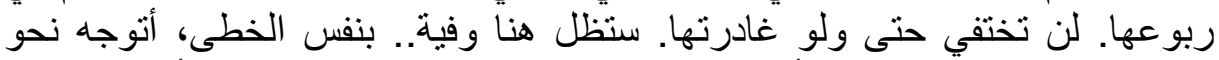

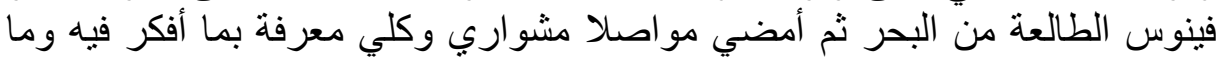

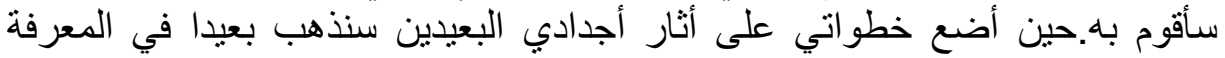

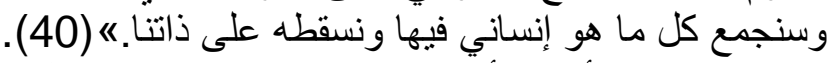

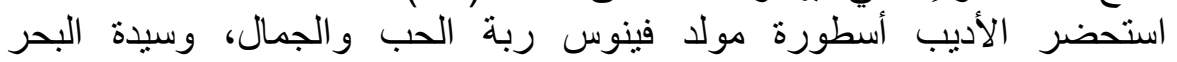

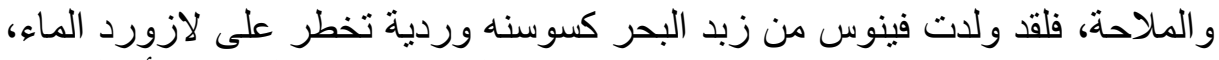

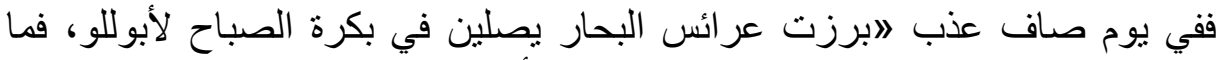

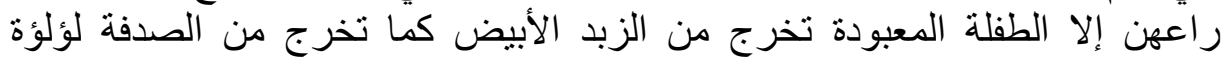

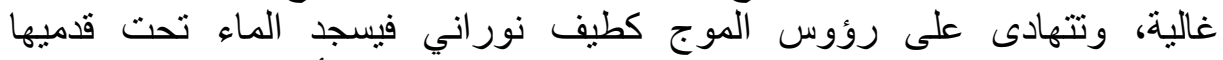

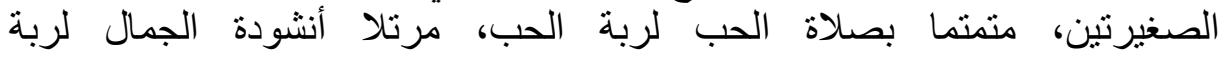

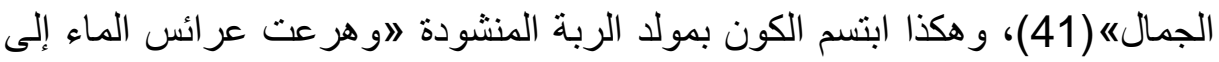

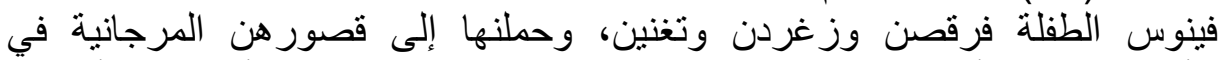

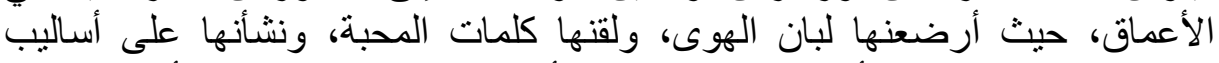

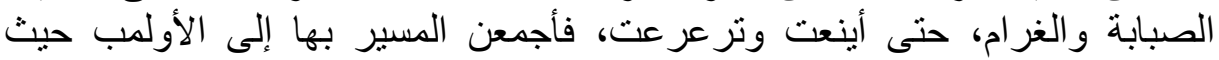

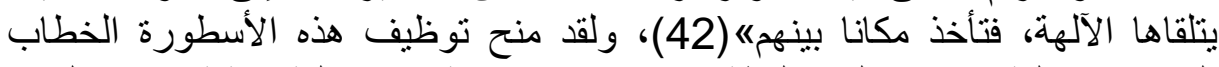

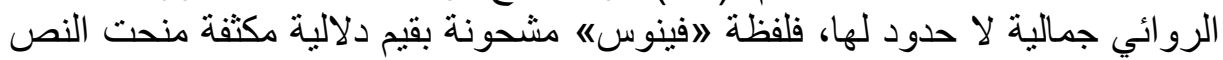

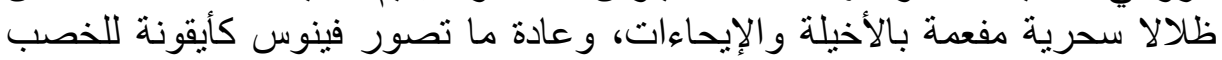

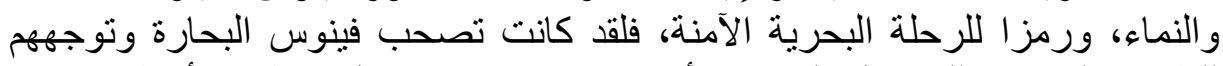

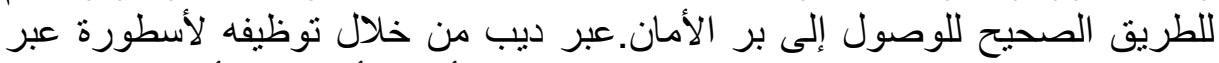

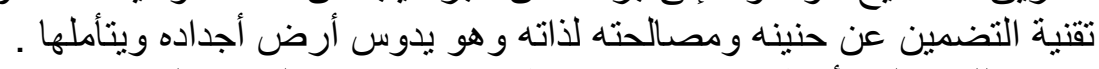

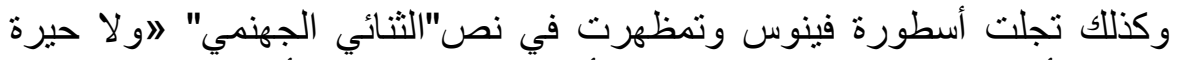

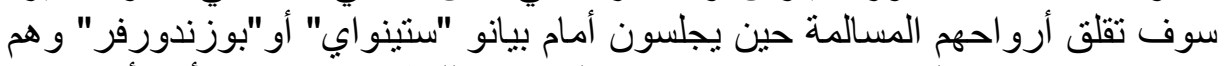

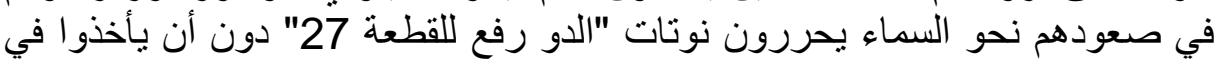
الحسبان وجود صديق ثان، وحش يجلس في حجر هم، بينهم و بين البيانو ويساهم في 
توجيه أصابعهم على الملامس والله وحده يعلم تللك الأشياء التي يفكرون فيها معا في

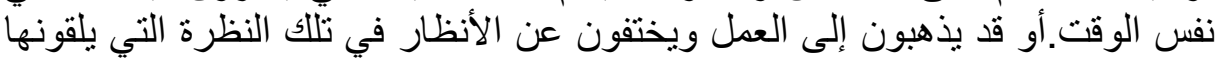

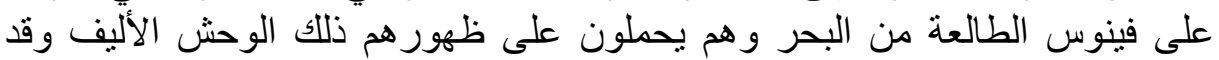

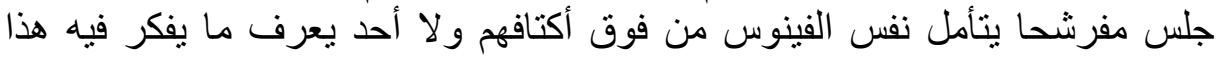
الصديق الحميم في تللك اللحظة. قد يرغب في مداعبة شعر وخدي تللك الطفلة الصغيرة

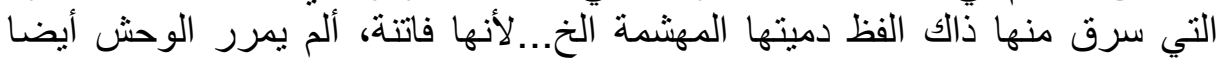

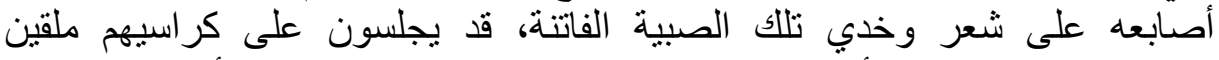
برؤوسهم إلى الخلف متأملين في الوقت الذي يقلدهم الوحش ملقيا بر أسه على على صدر

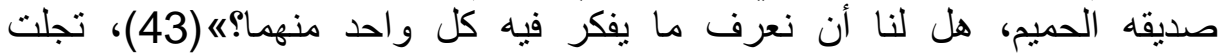

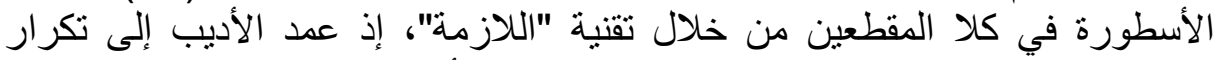

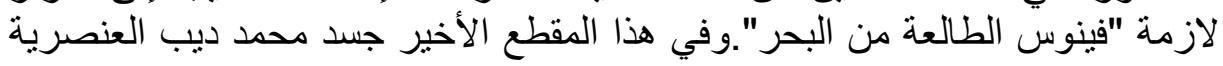
و جشاعة الإنسان.

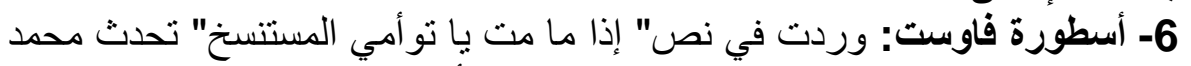

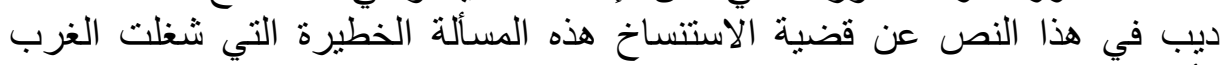

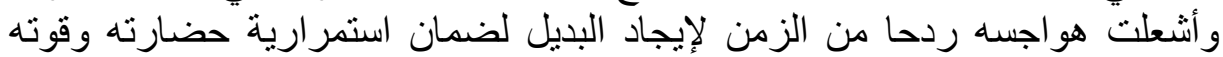

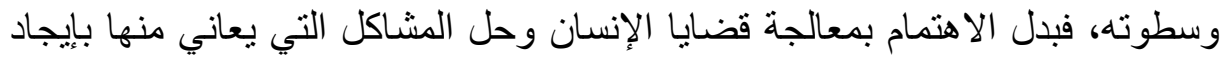

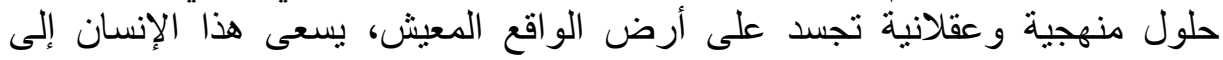

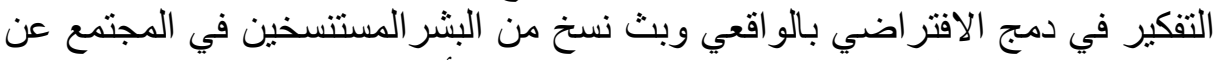

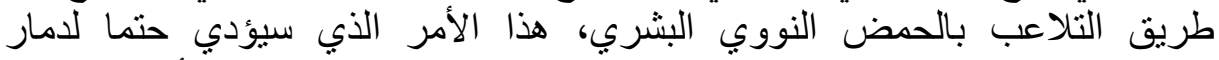

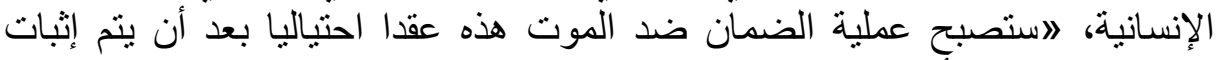

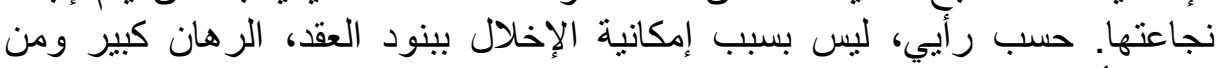

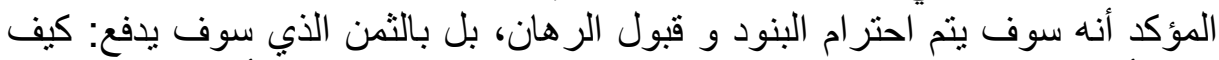

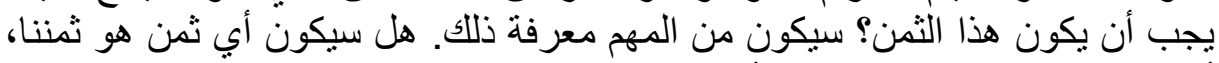

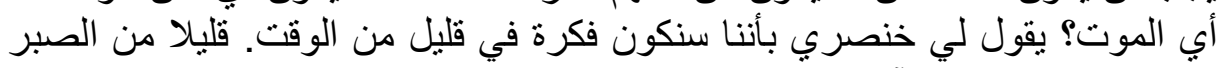

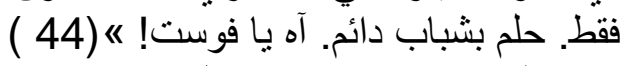

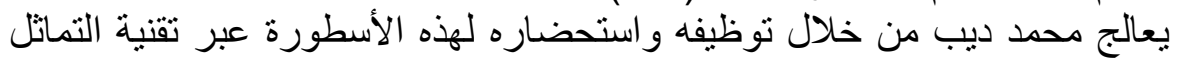

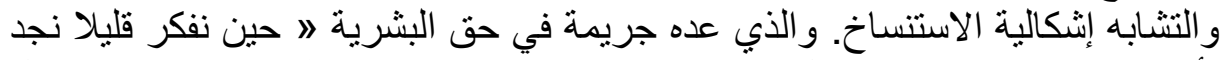

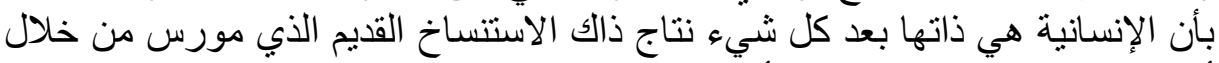

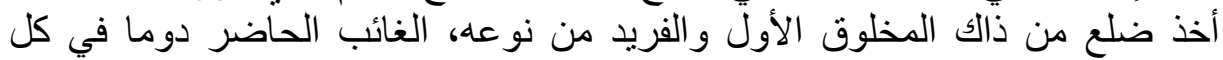

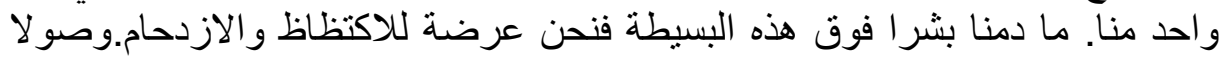

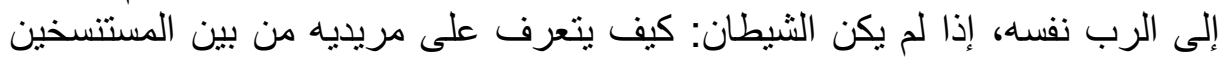

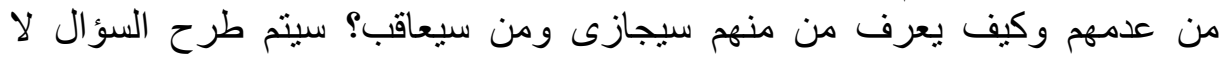

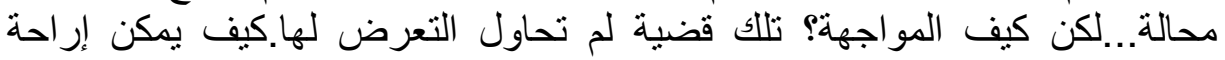

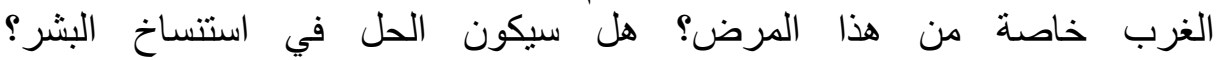

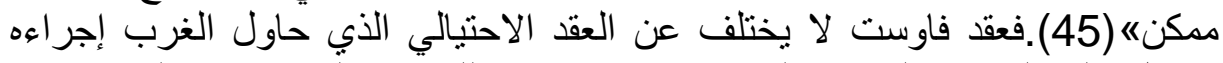

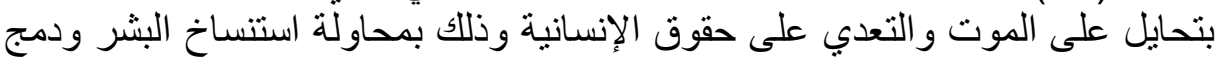

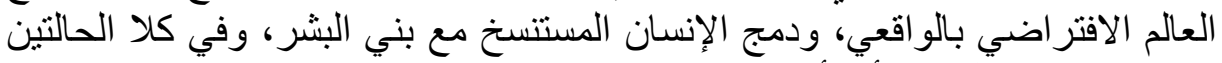
سيكون مصير الغرب أسوأ من مصير فالوست الإنسان لما في ذللك من تدمير للإنسانية و القضاء عليها.

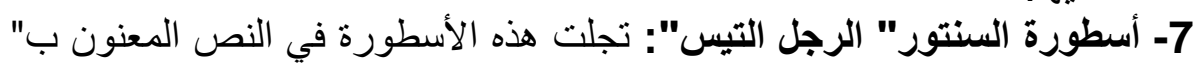

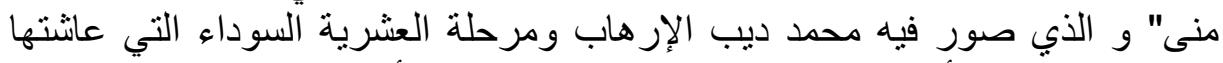

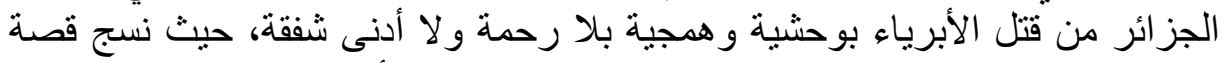

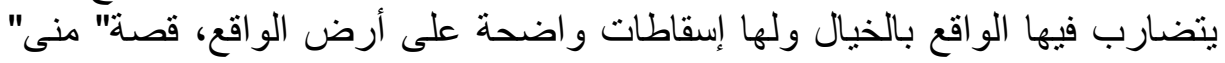


الطفلة الصغيرة التي لا تحسن الكلام مع الثناب التيس أو" الرجل التيس"هذا الرجل

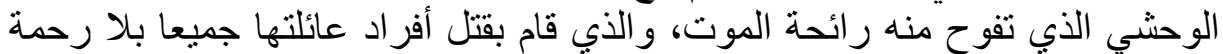

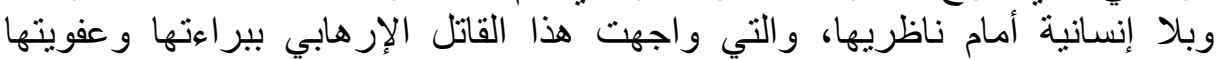

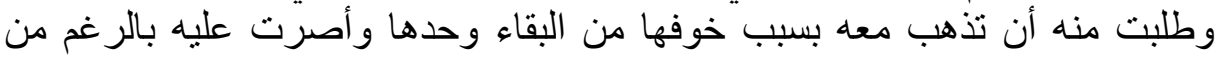

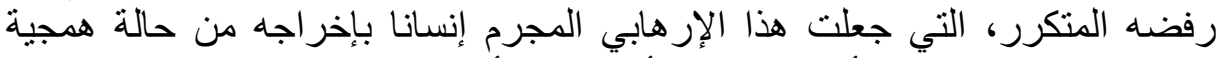
القتل وسفلك الدماء، بعد أن استطاعت أن تقنعه لأخذها معاله، و الذبي بعد تخليه عنها إنها

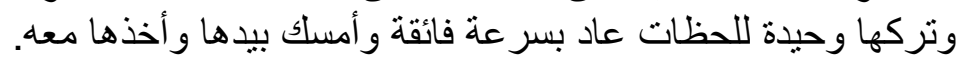

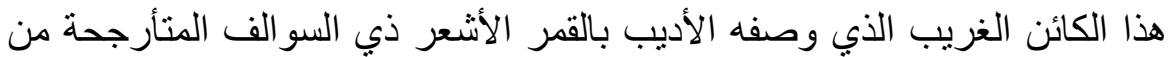

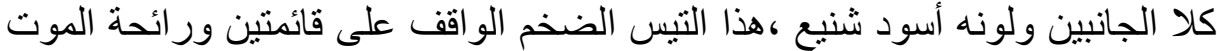

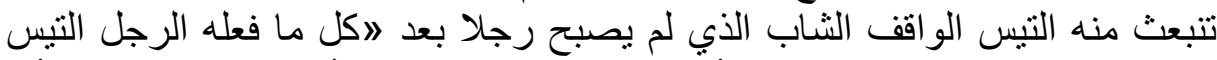

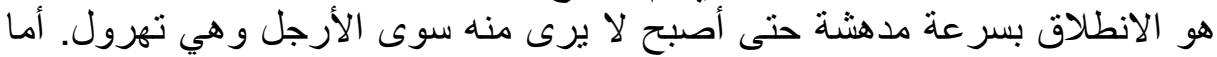

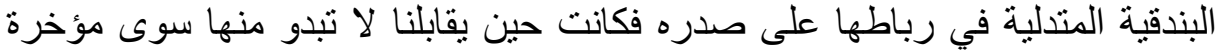

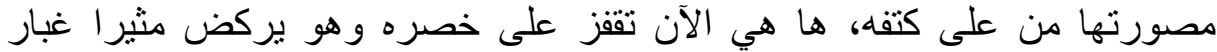

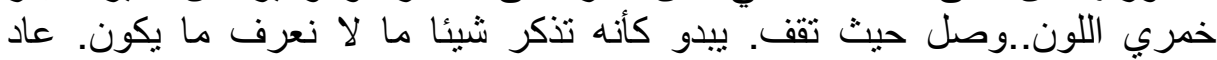

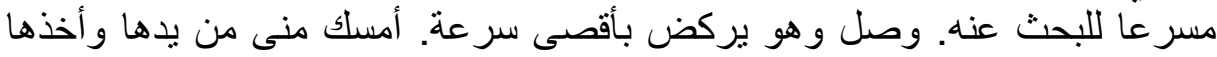

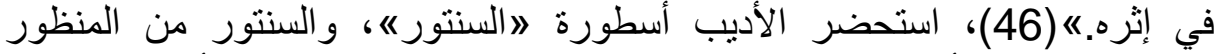

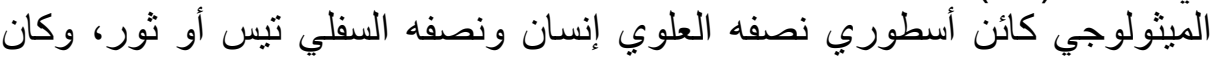

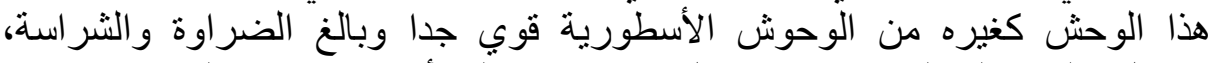

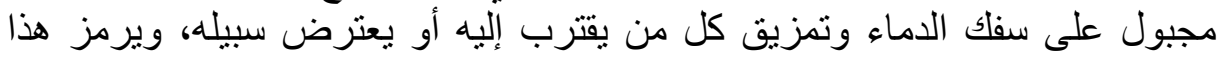

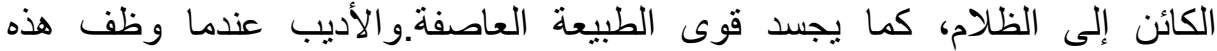

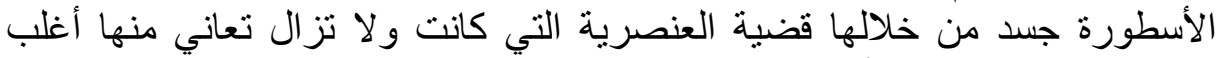

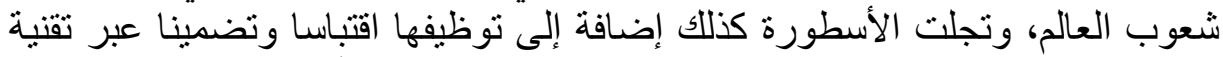

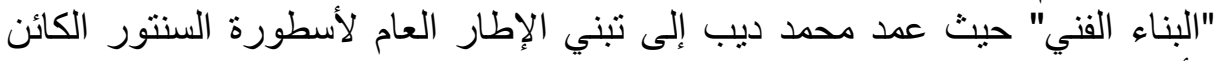

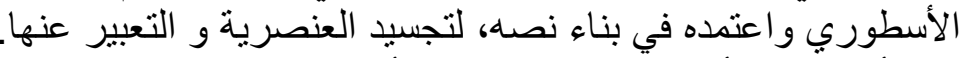

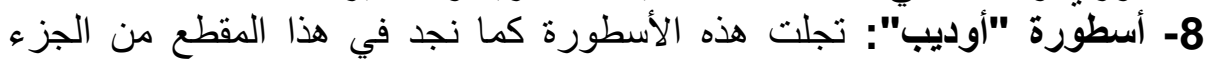

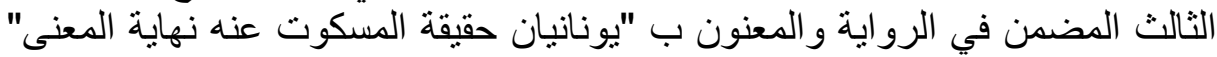

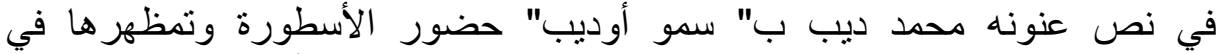

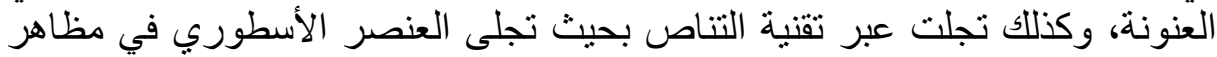

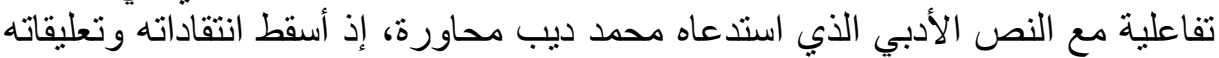

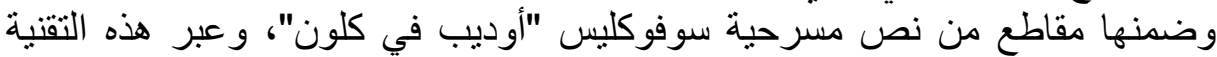
أعطى محمد ديب صورة معبرة بأن المرحلة الأخيرة من حياة الإنسان تماتلثل مرحلة

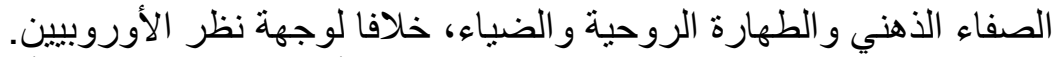

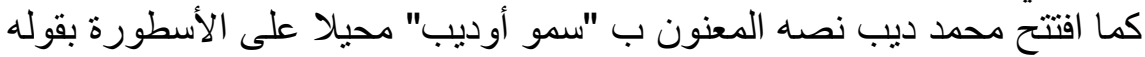

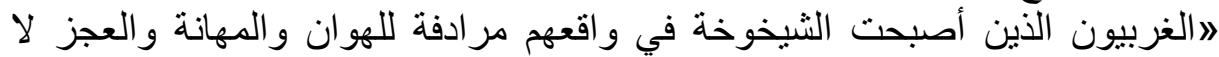

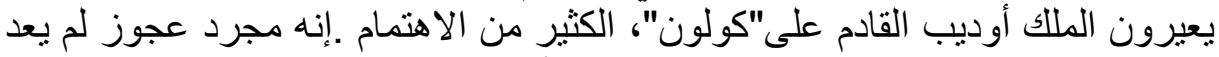

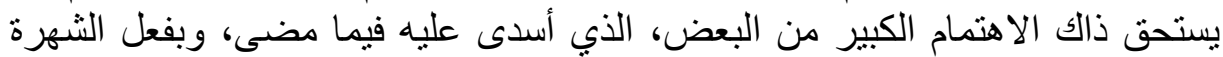

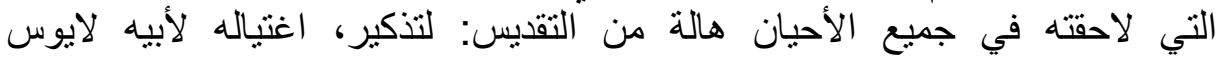

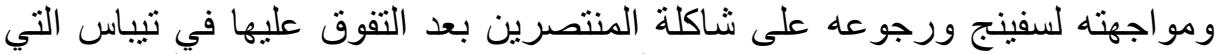

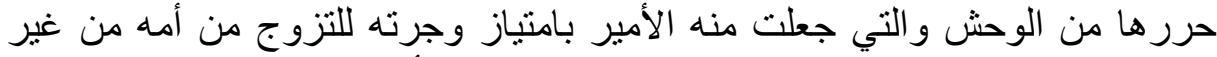

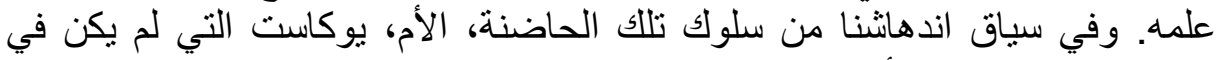

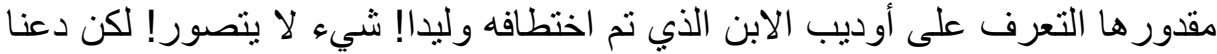

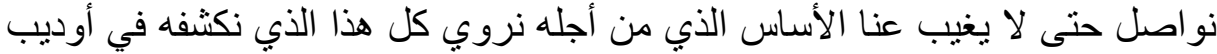

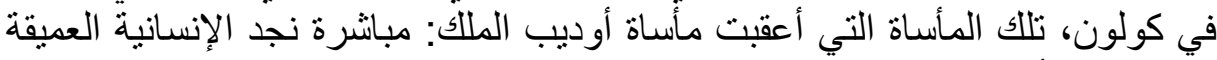

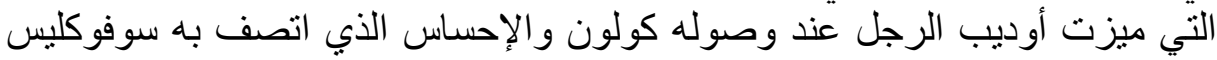
في نفس الوقت والذي يكبر مع التقام في العمر، فترتقي الإنسانية في تحول خافت إلى الى لـ 
القداسة وإلى البريق والانتشار الذي تحيط القداسة نفسها به....وإلا ما هو السبب الذي وجي إني

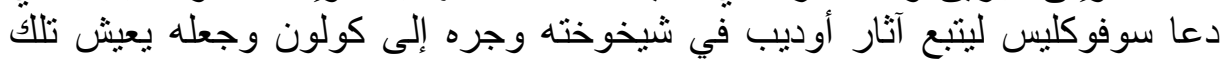

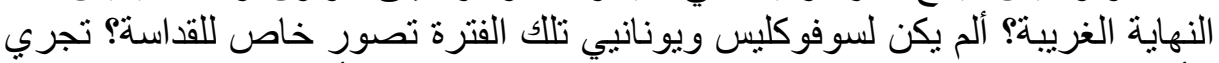

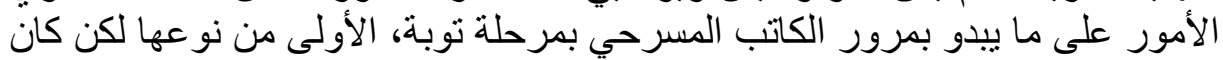

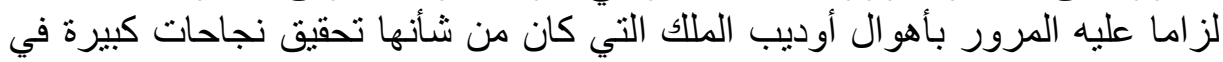

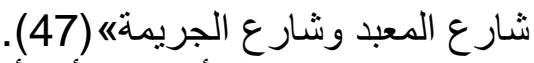

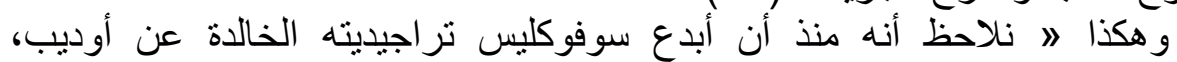

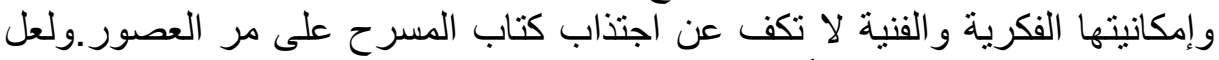

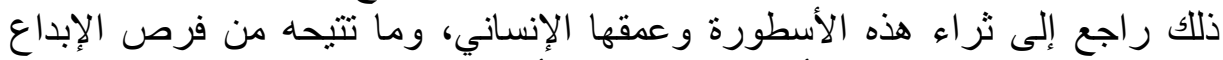

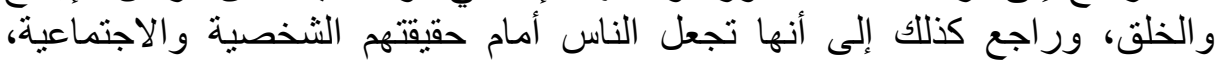

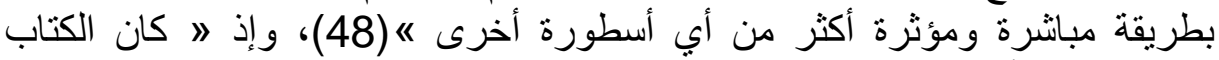

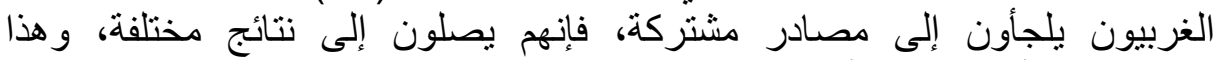

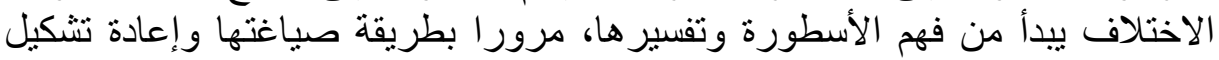

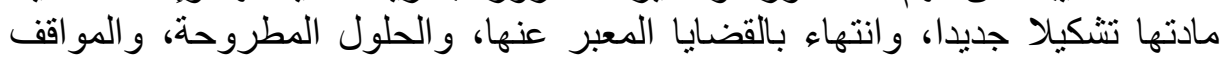

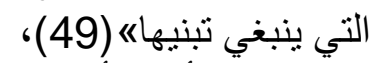

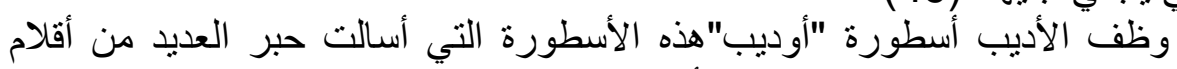

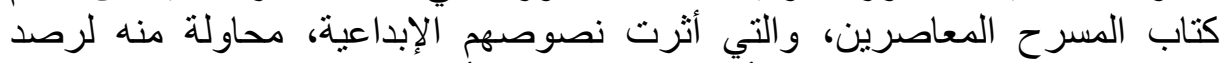

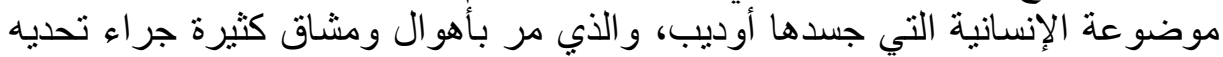

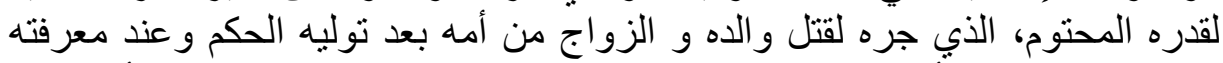

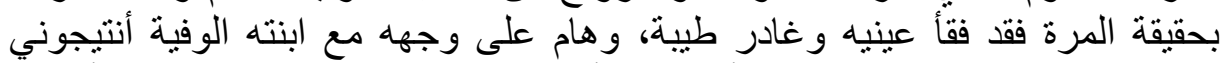

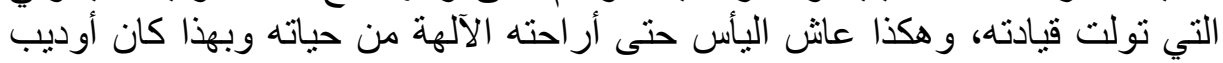

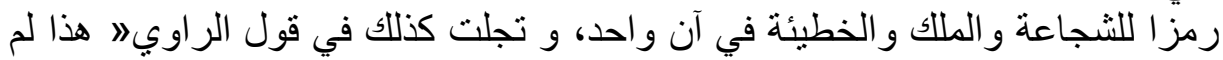

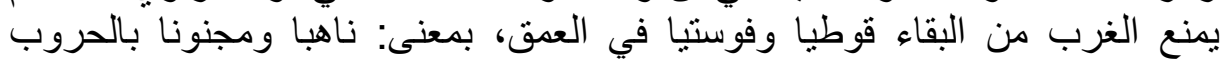

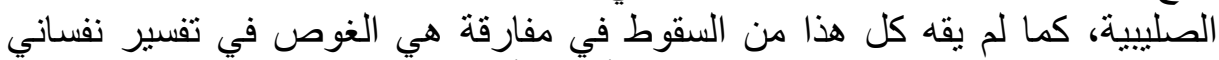

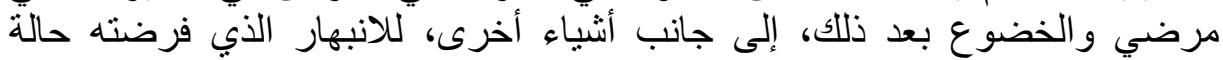

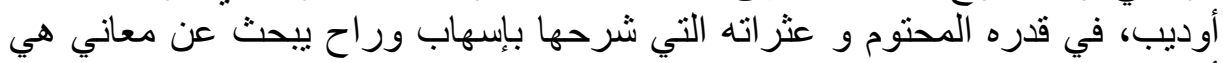

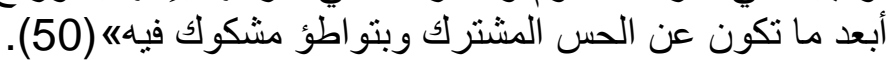

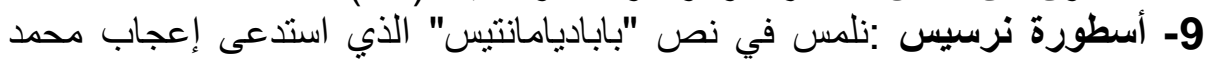

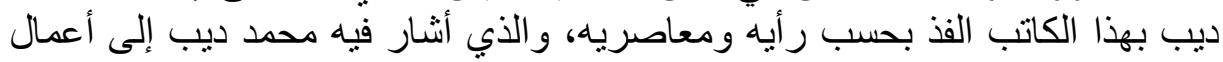

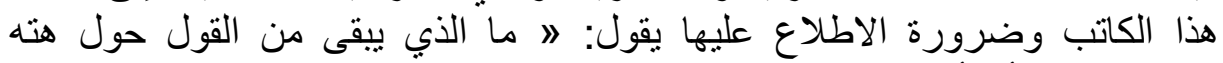

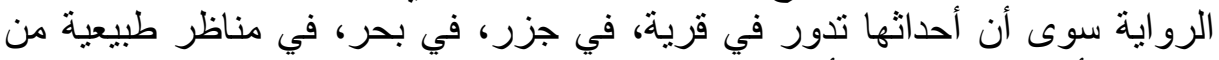

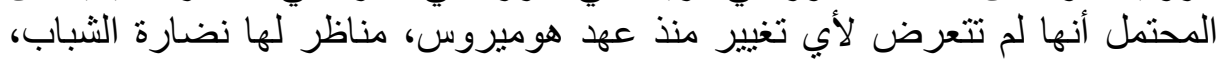

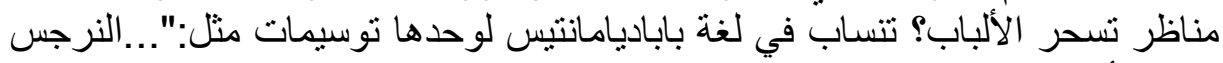

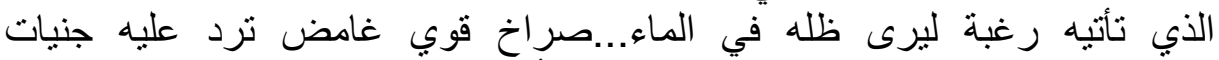

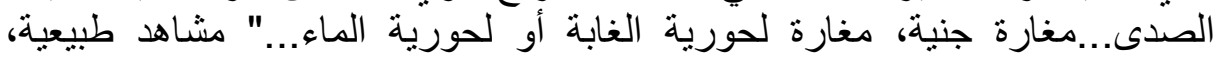

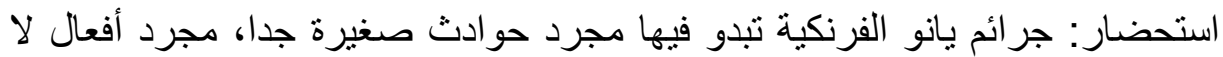

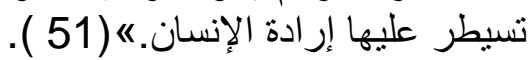
وظف الأديب أسطورة "نرسيس وإيكو" عبر تقنية التناص حيث اعتمد الإن مقاطع من

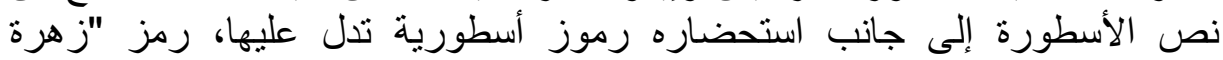

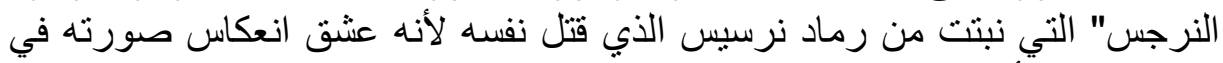

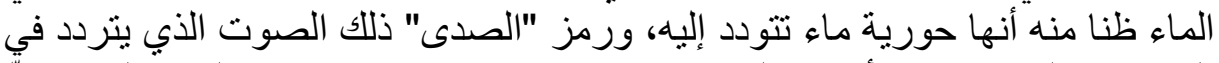

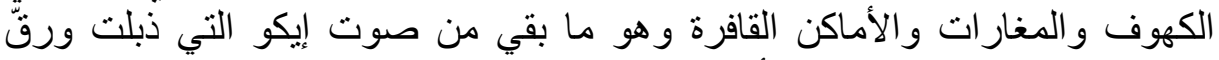

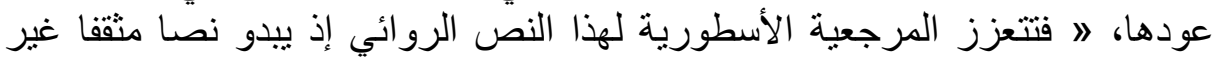


منغلق على أية ثقافة إنسانية، ومن ذلك الأسطورة الإغريقية المتعلقة بنرسيس الذي

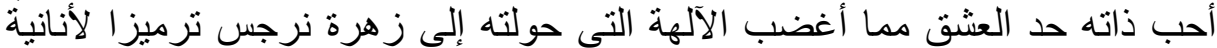

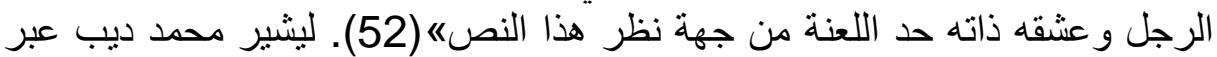

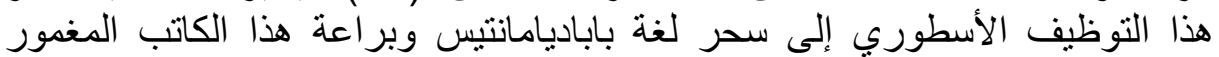

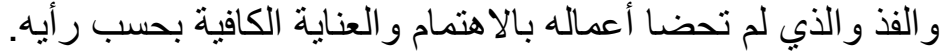

\section{～. V}

لقد أحدث توظيف الموروث الأسطوري في الخطاب الروائي المعاصر ثورة فكرية

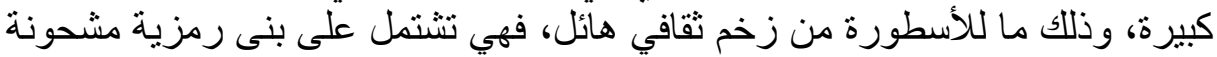

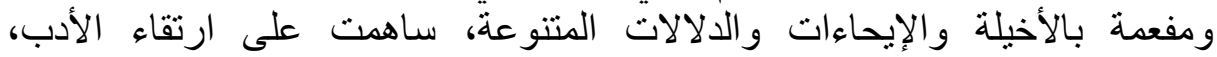

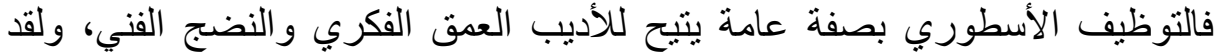

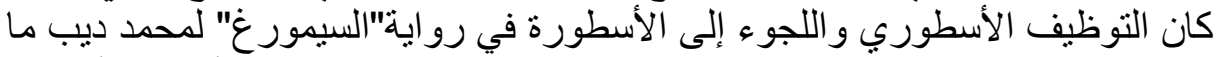

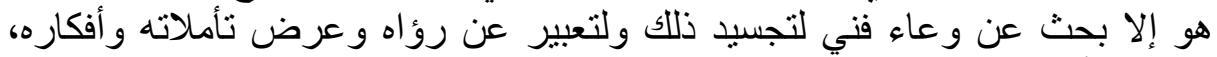

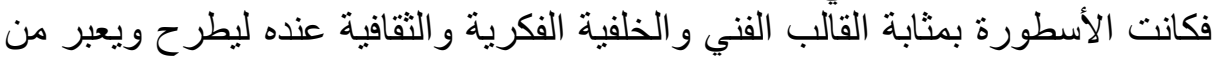

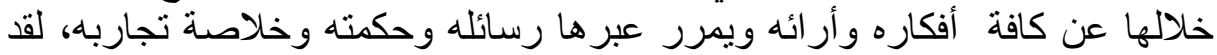

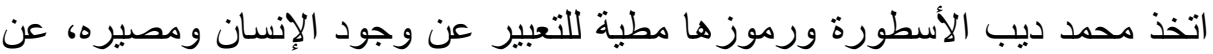

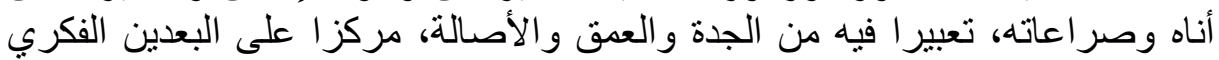
كما لامسنا ذلك من خلال در استنا لتجليات الرمز والأسطورة في ثنايا روايته والفني.

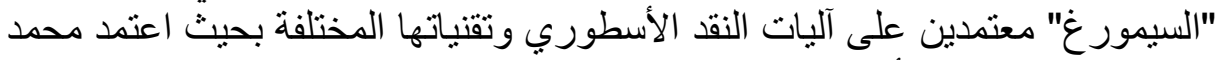

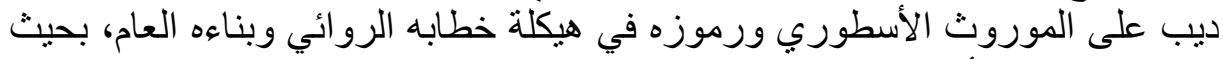

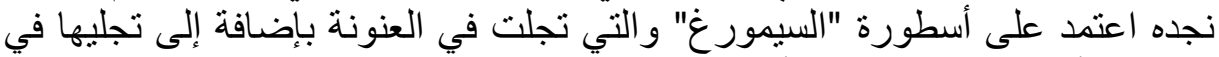

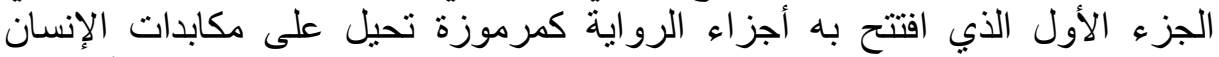

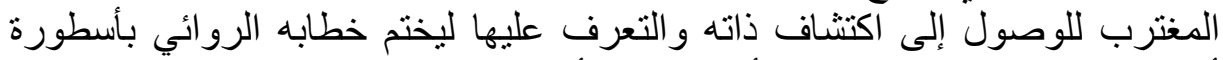

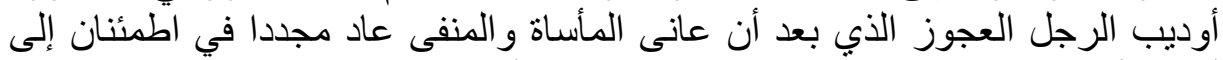

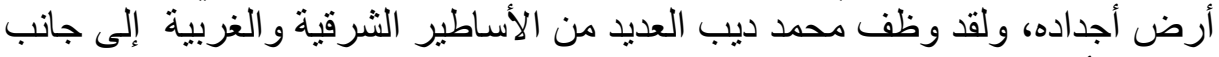

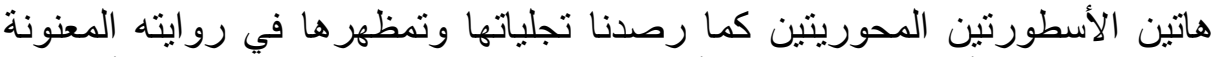

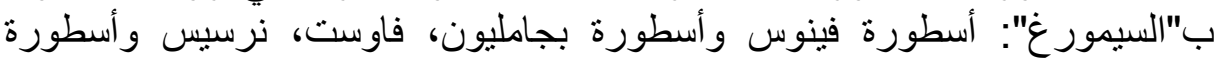

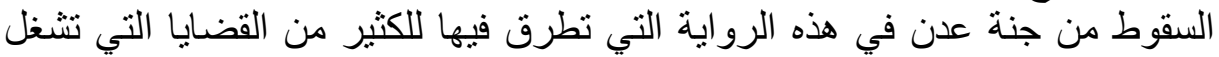

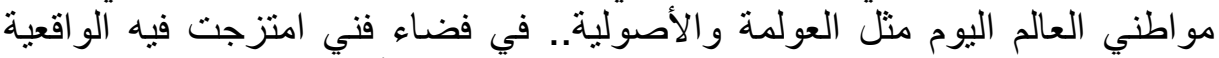

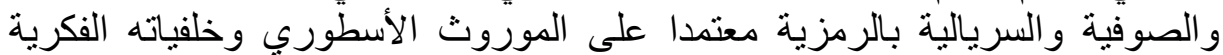
والثقافية كقالب عام لطرحها.

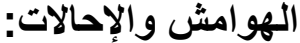

1جوزيف كامبل، البطل بألف وجه، تر حسن صقر ، دار كلمة، سورية-دمشق، ط1، 2003، 17. ص 2حميد علاوي، توظيف الأسطورة في مسرح توفيق الحكيم، الثارقة دائرة الثقافة و الإعلام،

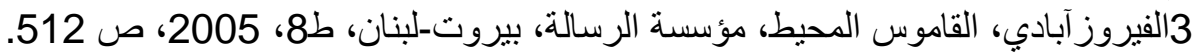

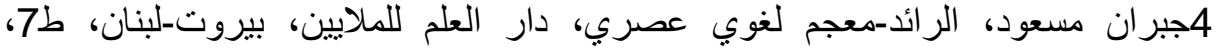

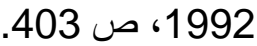

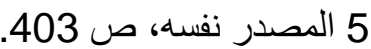

6روولان بارث، مبادئ في علم الأدلة، تر محمد البكري، دار الحوار، سورية-اللاذقية، ط2،

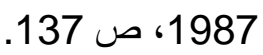


708لاح فضل، نظرية البنائية في النقا الأدبي، دار الثروق، القاهرة، ط1، 1998، ص

.308

8محمد فتوح أحمد، الرمز والرمزية في الثعر المعاصر، دار المعارف، مصر، (د/ط)،

1977، صد صن اح 35

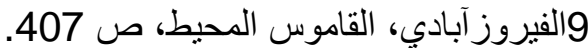

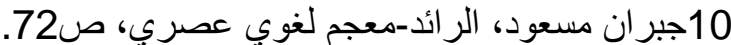

11فراس السواح، دين الإنسان-بحثث في مأهية الدئ الدين ومنشأ الدافع الديني-، دار علاء،

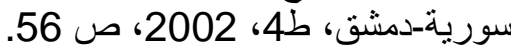

12 القرآن الكريم، سورة القلم، الآية 13.

13 القرآن الكريم، سورة الأحزب، لسورة الآن، الآية 6.

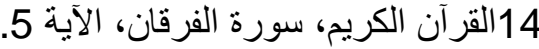

15مرسيا إلياد، مظاهر الأسطورة، تر نهاد خياطة، دار كنعان، دمثق، ط1، 1991، ص

16أحمد كمال زكى، الأساطير، الهيئة المصرية العامة للكتاب، (د/م)، (د/ط)، 2002، ص

17عبد الله الحمداوي، الأسطورة :الدفهوم المتعدد، من كتاب الأدب والأسطورة ،تأليف

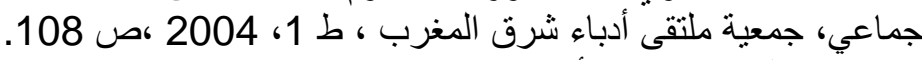

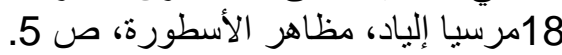

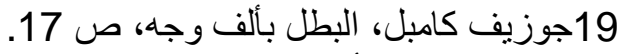

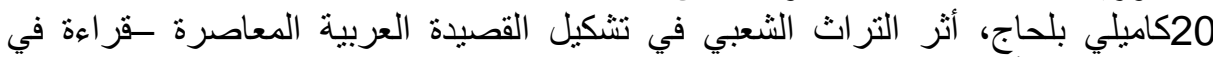

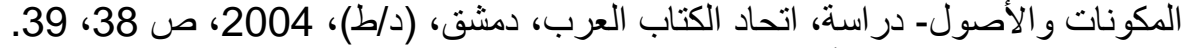

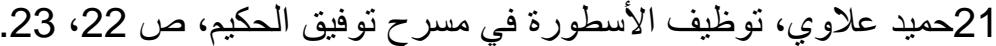

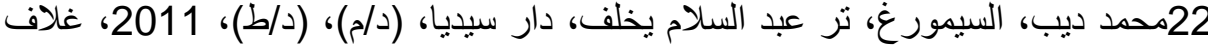

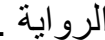

23نذير العظمة، سفر العنقاء حفرية ثقافية في الأسطورة، منشورات وزارة الثقافة في

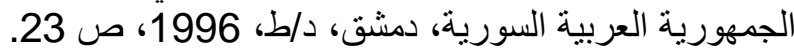

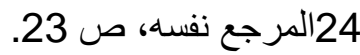

25نذير العظمة، سفر العنقاء حفرية ثقافية في الأسطورة، ص 124 124، 125.

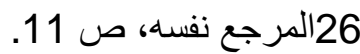

27محمد ديب، السيمور غن صن صن 21 20،20.

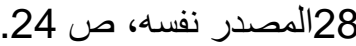

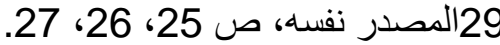

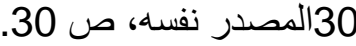

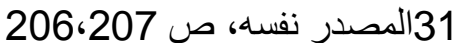

32عمر الدقاق، موسوعة الأعداد، ضلال الأعداد وهالاتها في الأساطير و الآداب، و الأديان

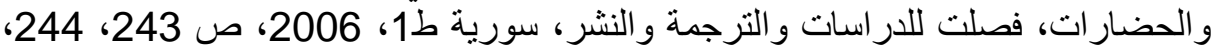

33 المرجع نفسه، ص 245 247، 248، 219، 249.

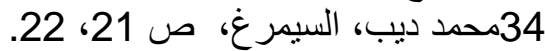

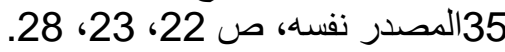

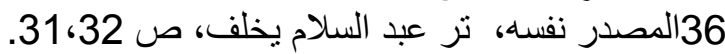

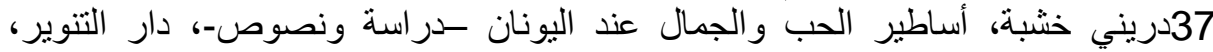

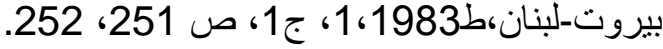

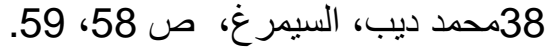
39 3 المصدر نفسه، ص203.

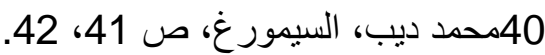

41دريني خشبة، أساطير الحب و الجمال عند البونان سـراسة ونصوص-، ص 227. 


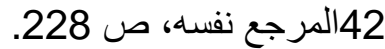

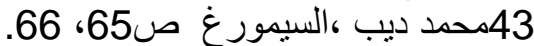

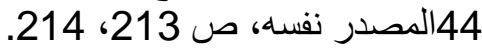

45 4حمد ديب، السيمور غ ،ص 217 217، 218، 218، 220.

46 المصدر نفسه، ص 228، 289، 229.

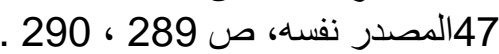

48 يونس لوليدي، المسرح والأسطورة، المركز الدولي لدراسات الفرجة، الدغرب، ط1،

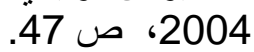

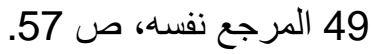

50محمد ديب، السيمور غن، ص 579

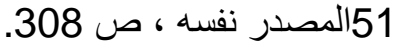

52صبري مسلم، النقد الأسطوري والأنساق السردية والثعرية والمسرحية، الجمهورية

اليمنية وزارة الثقافة والسياحة، صنعاء، د/ط، 2004. ص الأس 34. 